\title{
Exploring the Sphinx and the Great Pyramid Through the Logos Heuristics
}

\author{
Antonio Cassella ${ }^{1}$ \\ ${ }^{1}$ President of Research Autism LLC (FL) and Director of Imerisya (Instituto merideño de investigación de la inteligencia \\ social y del autismo, Mérida, Venezuela). \\ Correspondence: Antonio Cassella, 1270 N. Wickham Rd. 16-613, Melbourne, FL, 32935, USA.
}

Received: July 6, 2018

Accepted: August 3, 2018

Available online: August 20, 2018

doi:10.11114/ijsss.v6i9.3559

URL: https://doi.org/10.11114/ijsss.v6i9.3559

\begin{abstract}
The author describes a triangulation in ancient Egypt: the crossing of a 22.5-mile (diameter) northern circle with an 18-mile southern circle around a shared baseline, which goes eastward 14.1 miles from the vertex of Khafre's Pyramid in Giza. He hypothesizes that in the $26^{\text {th }}$ century before the Common Era, Pharaoh Khufu (Khafre's father) leaned on that triangulation to freeze in stone a master plan, in which the first step was replacing with hope the fear of Egyptians for the monumental catlike goddess that preceded by 65 centuries Giza's Sphinx. Khufu re-sculpted the head of the eastward-looking lioness into the head of the Pharaoh-Guardian of Upper and Lower Egypt. In so doing, the subluminal speed of the first attention, memory-brotherhood in classical computing, and the Sphinx's head joined the superluminal speed of the second attention, hope-creativity in quantum computing, and its body. The Sphinx and the Great Pyramid that followed its transfiguration point at the union of the first and the second attention into the Third Attention. As a reflection of Khufu's master plan and the Third Attention, the logos heuristics connects here Egyptian monuments with the roots of nature, the complex plane, global cooling, autism, madness, open discourse, brainwaves, mysticism, music, Leonardo's art, meditation, the return of the Mesoamerican demigod Quetzalcoatl, motherly love, and progress.
\end{abstract}

Keywords: Sphinx, Great Pyramid, nature's nature, brotherhood, hope, progress

\section{Introduction}

Since 10000 BCE (before the Common Era), memory of the increase of sea level (by 75 meters) and air temperature (by 4 degrees Celsius) during the previous 10000 years may have heightened the will of Egyptian rulers to transform problems into opportunities of growth. In the 26 century BCE, a drier climate did not stop Pharaoh Khufu from turning the Fourth Dynasty into a beacon of hope and progress.

By contrast, our aim to multiply and live better, within lesser space, gloomy life, and faster death for nonhuman species, is dulling hope, while awakening a dragon in the sea and the back of our minds. If the temperature of the lower atmosphere increases by 2-3 degrees Celsius, sea level will rise by seven meters first - as it did 125000 years ago, and then, it will increase by 63 meters in 5000 years.

The end of a prolific, consuming (Cassella, 2008), and inhuman civilization needs not wait that long. Besides joining the intensification of autism, alienation, and terrorism, in less than one century rising seas may join the inordinate release into the atmosphere of green gases and hydrogen sulfide. The destruction of the ozone layer (Ward, 2006) and the degeneration of our minds (Cassella, 2018c) might obliterate two thirds of the biota. Although they remained surrounded by beauties, weapons of mass destruction, a cult of personality, and a castrating ideology, incompetent leaders and their reckless followers will find no hole in which to hide.

Among the competent leaders freed by Cyrus the Great, Zechariah warned us (11-13; Katznelson, 1991) that our recklessness will compel God to break his staff No'am (flexible hope in the Sphinx's body); and after that, his staff Hovalim (rigid brotherhood in the Sphinx's head). According to Zechariah (13:08), "Two parts of all Earth will die." In implicating the alliance of No'am with Hovalim, or the second with the first attention, however, Zechariah's warning may help us transform looming catastrophes into progress.

The first attention ("Hovalim," the Olmec-Maya-Toltec-Aztec "Snake-Coatl-Tonal," the Jewish "Thummim," and the head of the Sphinx) sustains certainty in classical computing, known memories, the ritual obedience celebrated by Kong Fuzi (Confucius), the law, the knowledge conserved by science, the legitimacy that abandons the "Bird-Quetzal" of schizophrenics, and semantics-syntax in our cerebral autistic side. 
The second attention ("No'am," the Jewish "Urim," and the body of the Sphinx) sustains doubt in quantum computing, the departure to Venus of the Olmec-Maya-Toltec-Aztec "Coatlquetzal-Nagual," unknown memories, lies, the paradoxes celebrated by Laozi, pretend play, and discourse pragmatics in the cerebellar circuitry weakened in autism.

Instead of limping, our second attention might embrace the infinite speed of quantum coherence; as did Muhammad in reaching the Farthest Mosque. Within the decoherence of Muhammad's ageless return to Mecca and Quetzalcoatl's return, if our Third Attention checked overambitious leaders, our minds will fathom:

-the kindness of the Archangel Gabriel, Abraham, Moses, and Jesus.

-Arjuna's Gandiva bow and inexhaustible quivers;

-the stepping of the Virgin of Guadalupe over the extreme wit of the Moon-Coyolxauhqui;

-the implications of the meeting of Kong Fuzi with Laozi;

-the roots of nature and the mind charted by Zechariah; and

-the magic that pursued progress in Zoroaster's Magi.

In the $2^{\text {nd }}$ millennium BCE, while Zoroaster broadened Western Asia, the Mesoamerican Olmecs-Maya celebrated the going journey of a demigod - the "Nagual-Snakebird" (or "Coatlquetzal" in the Nahuatl language of $13^{\text {th }}$-century-CE [Common Era] Aztecs) - with the ambiguity of the Moon-Coyolxauhqui and a fading Morning Star. "Quetzalcoatl" ("Plumedserpent", or the "Eagle holding a serpent") will mount the increasing luminosity of the Evening Star and return to Earth with the secret of the Third Attention (Cassella, 2018c). The Aztecs and their Spanish "Conquistador" (Hernán Cortés) never grasped the union of the classical Tonal and the quantum Nagual in the Eagle of the Third Attention that returns with Quetzalcoatl (Cassella, 2018c, 2018d).

One millennium before the Olmecs, Pharaoh Khufu hid the Third Attention in two monuments located about 13 miles north-west of Memphis - his capital. After Khufu transformed Giza's lioness into the Sphinx, eager Egyptians built there the Great Pyramid. Perhaps 6500 years before the Fourth Dynasty, a head-priestess enclosed quantum computing in the lioness that preceded the Sphinx; and about 30 millennia before her, in Gibraltar-a five-hour swim to Africa, Neanderthal humans traced in Gorham's Cave a symbolic crossing (Rodríguez-Vidal et al., 2014) about the alliance of classical computing in our conserving facet with quantum computing in our creative facet. In time, the social alliance of conservation and creativity — admired by powerful priestesses and kind rulers — was forgotten.

Although the scoop of diggers has funded the advance of Egyptology, the ultimate reasons for building Giza's Sphinx and the Great Pyramid remain mysterious.

I will recap next how I explored Giza's monuments. Following Collins' (2007) correlation theory, I turned and contracted a map of northern constellations over a view of Greater Cairo, seeking the convergence between the three wing stars of Cygnus and the pyramids of Khufu, his son Khafre, and his grandson Menkaure. My experience with topography suggested that in the $26^{\text {th }}$ century BCE the Egyptian "House of Thoth" (the god of wisdom) had replicated on land the celestial crossing of two circles, implied by the Northern Cross (in Cygnus). Because Egyptian sages crossed an 18-mile (diameter) circle south of Giza with a 22.5-mile circle north of Giza, I concluded that Egypt's primary triangulating network included Earth's sphericity.

Ancient Egyptians lacked the theodolite I used to observe azimuthal and zenithal angles. Still, they paralleled the Northern Cross, the Leo asterism, the Sun, Sirius in Canis Major, and the Orion Belt with several monuments: four major pyramids in Northern Egypt; the Sphinx; a temple to the sun-god Ra (13.5 miles east of the Sphinx's head); a temple to Sopdet-Isis-Sirius (south-east of that location); and three temples to Sah-Osiris-Orion, 1.8 miles of $\mathrm{Ra}$ - ascending the eastern side of the northern circle of triangulation.

After sizing the baseline of their two triangulation-circles, Egyptian surveyors replaced distance measurements with the crossings of angles. Possibly, their triangulation-circles validated through day-mirrors and in darkness the location of the illuminated benben-pyramidions on their obelisks and pyramids. Instead of walking, they "flew" over flooded land, rugged deserts, and urban dwellings. In the $26^{\text {th }}$ century BCE, Vizier Hemiunu and Pharaoh Khufu flew over time by freezing in the Sphinx and the Great Pyramid a "master plan" that involved their two triangulation-circles and a message:

Awareness of the universal pervasiveness of the Third Attention will allow the young to replace the chaos of global warming with the progress of global cooling.

Undermining natural global cooling will menace the survival of nonhuman species, our grandchildren, progress, and the understanding of our Sacred Texts. Our incapacity to learn through prayer, and to re-create the Divine by helping our young to adopt the kind use of quantum computing, has been unleashed by undigested technological growth and cultural shock. Still, this paper posits that all Sacred Texts, the Sphinx, and the Great Pyramid support kindness in the social empathy that wins with others. 


\section{Method}

The questions and answers outlined in the introduction, discussion, and conclusion are supported by the constructs presented in the next background section.

\section{Background}

\subsection{The Construction of Four Greater Pyramids in Northern Egypt}

In the second century BCE, Antipater of Sidon described Khufu's Great Pyramid among the Seven Wonders of the World. The story of true pyramids began at the turn of the $27^{\text {th }}$ century BCE, when Pharaoh Sneferu returned to Egypt from Libya and Nubia with numerous prisoners and cattle (Guillemette, 1997). He used his pillage to build three pyramids south of Memphis. The Greek historian Herodotus wrote in the $5^{\text {th }}$ century BCE (Laertius, $6^{\text {th }}$ century CE, 2017) that besides extending the know-how he picked up from his father Sneferu, Khufu too relied on authority to build the Great Pyramid. The difficulty to drain twice-in-a-row Egypt's neighbors, however, left Khufu with one alternative: convince his compatriots to follow a shared dream.

Cutting and placing almost perfectly 2.3 million blocks, each with an average weight of 2.5 tons, allowed Egyptian skilled hands to shape the Great Pyramid into a dimensionless point. The 440 royal cubits in each side of its squared base form a perimeter of 1760 cubits. Dividing that perimeter by the 280 -cubit height of the Great pyramid gives about twice the Greek Pi (3.14159 . . toward infinity and nothingness), or Tau (6.28318 . . toward infinity and nothingness).

Khufu's technical and social secrets reached Khafre, his third son, who built a pyramid with shorter sides (411 cubits) and lesser height (274 cubits) on a contiguous higher ground. Before Khafre, Pharaoh Djedefre (Khufu's second son) erected a smaller pyramid north-west of Giza; and Khafre's successor, Pharaoh Menkaure, built the smallest pyramid at the southern edge of the arch formed by the three largest pyramids of Giza (figure 1).

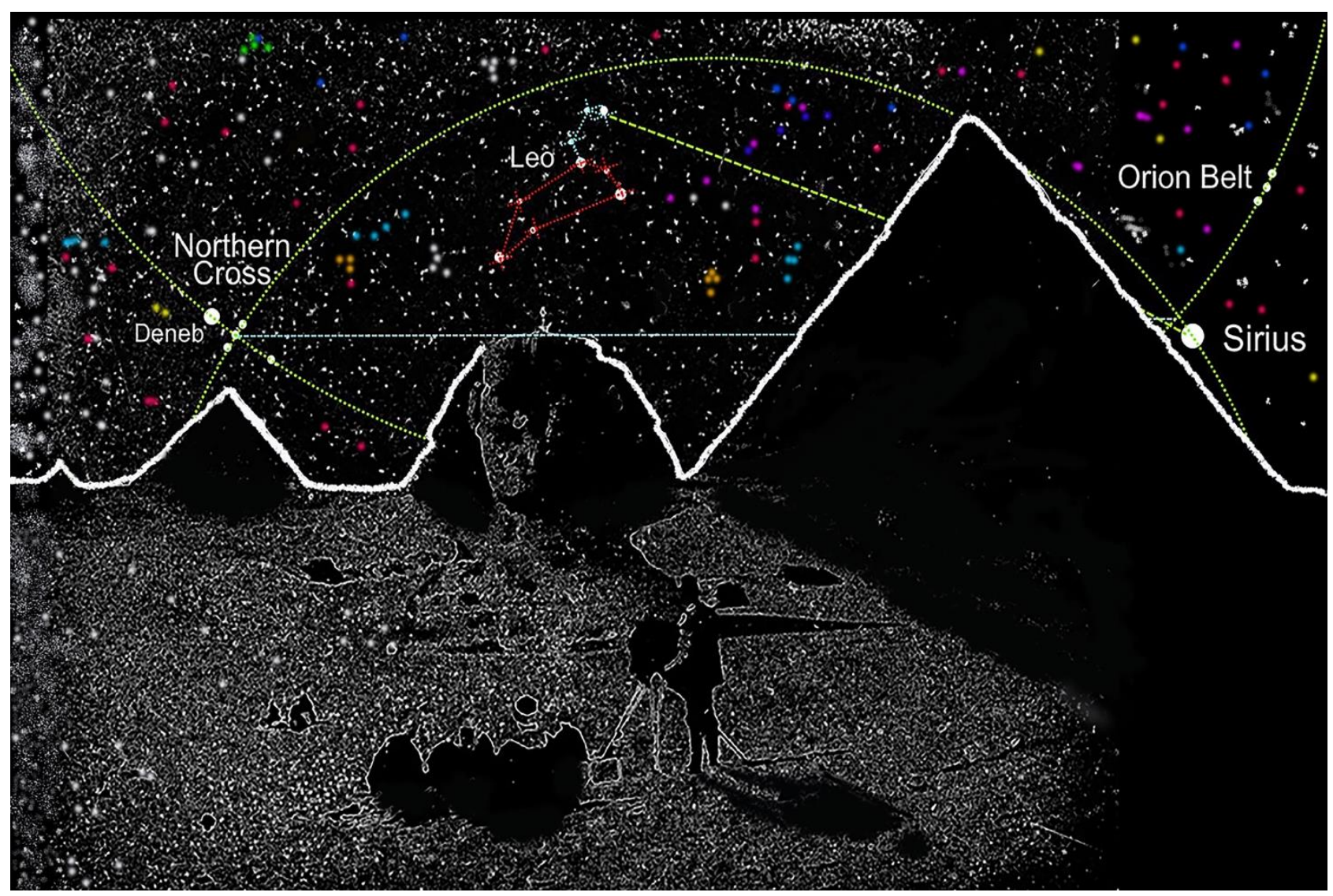

Figure 1. Giza's Sphinx and pyramids in the late $1800^{1}$

The sand that covered the leonine body of the Sphinx facilitated vandalism by the fanatic who broke its nose in the $14^{\text {th }}$ century. Hanging the perpetrator did not solve the mystery about the monuments of Giza.

${ }^{1}$ (Public domain, @.) The author reworked the sky and shadows. 


\subsection{The Mystery Behind the Construction of the Sphinx}

Mark Lehner (1997) and Zahi Hawass (1998) proposed that re-crystallization of salts in the pores of the Sphinx corroded its shape and the power of the pharaohs of the $4^{\text {th }}$ Dynasty. Following the discovery of an incomplete royal cartouche with the name "Khafre" in line 13 of Thutmose IV's Dream Stela and other contextual evidence, Hawass, Lehner, and most academic Egyptologists attribute the construction of the Sphinx to Khafre. Accordingly, the information from the $6^{\text {th }}$-century-BCE Inventory Stela that Khufu uncovered an already buried monument is dismissed as historical revisionism.

Interpretations that attribute the construction of the Sphinx to Pharaoh Khafre are challenged by the following observations:

a) Geologist Robert Schoch (1995) wrote that vertical erosion in the upper body of the Sphinx can be attributed to precipitation weathering;

b) Rainer Stadelmann (2003) asserted that the neme-headdress of the Sphinx points at Khufu;

c) Frank Domingo, a forensic scientist of New York's Police, found minor resemblance between the squared jaw of the Sphinx and the face of Khafre;

d) Colin Reader (2006) concluded that Giza's Causeway was built around the Sphinx; finally,

e) the small pharaonic head of the Sphinx is incongruent with its large body. (See the balloon in figure 2.)

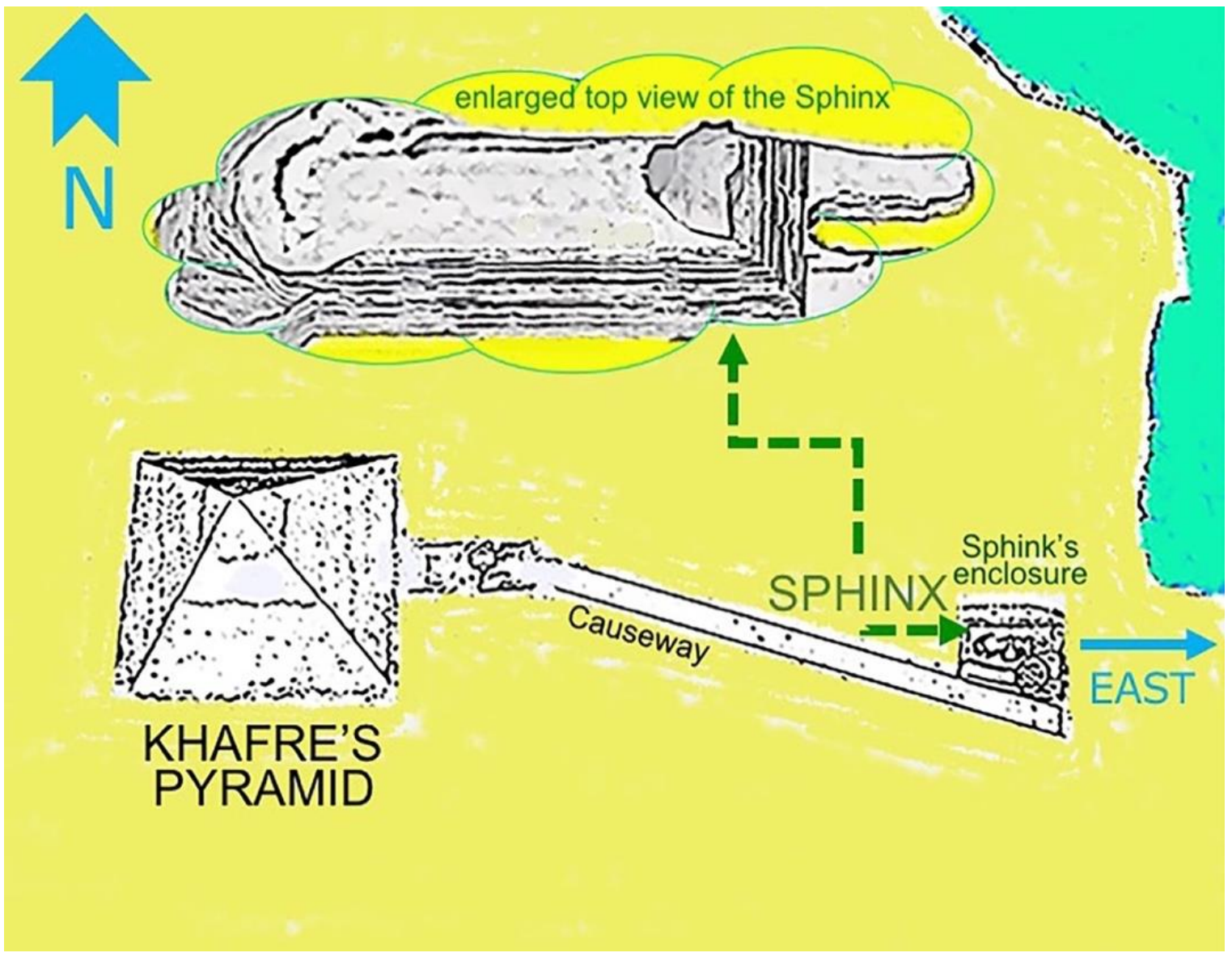

Figure 2. Situation of Giza's Sphinx ${ }^{2}$

\subsection{The Orion and the Cygnus Correlations}

Among other fringe interpretations, I will recap first the Orion Correlation Theory. Bauval and Gilbert (1994) hypothesized that ancient Egyptians equated the three pyramids of Giza with the Orion Belt; and the Sphinx, with the asterism we now call Leo. In line with Edgar Cayce's transcendental dreams about a vanished Atlantean civilization, Bauval and Gilbert proposed that the Sphinx was built around 10500 BCE.

As to the Cygnus Correlation, Andrew Collins (2007) showed that the three wing stars of the Cygnus constellation make

${ }^{2}$ The author superimposed an enlargement of the Sphinx on a picture he took through Google Earth Pro in July 2018. 
the celestial match in 2500 BCE to the earthly setting of the pyramids of Khufu, Khafre, and Menkaure.

The mystery about the Sphinx and the Great Pyramid compels me to signal further perceptions.

\subsection{Pythagoras' Debt to Babylonians and Egyptians sages}

Following a logic reinforced by Diogenes Laertius, prior to moving in the $6^{\text {th }}$ century BCE from Greece to Croton (Southern Italy), Pythagoras had learned arithmetic from Phoenicians; astronomy, from Chaldeans; religion, from Zoroastrian Magi; and geometry, climate change, and music, from Egyptians.

Pythagoras then applied the consonance related to the perfect octave (based on the ratio 2/1), fifth (3/2), and fourth (4/3) in a musical scale that enclosed 12 rational proportions from the unison. Twenty centuries later, Vincenzo Galilei (the father of Galileo Galilei) found that within an octave composed of 1200 cents, the Pythagorean harmony lacked 23.4 cents to close the circle: The Pythagorean Comma. Vincenzo's findings compromise Pythagoras' implication that mathematical rationality captures the harmony of the universe.

Within mathematics and geometry, the theorem by which the square of the hypothenuse of a triangle-rectangle equals the sum of the squares of its two catheti is attributed to Pythagoras. The application of Pythagoras' theorem to a square with side unity produces the irrational value of its diagonal: $\sqrt{2}$. The result accentuates the need and insufficiency of rational postures.

Ancient Egyptians either knew Pythagoras' theorem or used the proportions 3, 4, and 5, in a right triangle, to trace the perpendicular they needed to draw the squared base of their pyramids. The irrational diagonal of any square is also the rational diameter of the circle that contains it.

In the complex plane, the diameter of the unitary circle underlies the irrational and transcendental angle Greek $\mathrm{Pi}(\pi)$ measured in radians. About 24 centuries after Pythagoras, the mathematician Leonard Euler stepped on the complex plane and the ratio (Greek Pi) of a circle's circumference to its diameter to arrive at "Euler Identity."

\subsection{The Case of Euler Identity and of the Tau Identity}

Because Euler Identity reenacts the going voyage of the Mesoamerican demigod "Coatlquetzal," I follow Cassella (2018a) in completing the return of "Quetzalcoatl" to reality through a twice-Greek-Pi (Tau, or $\tau$ ) angle in radians (in Euler's formula), or the ratio of a circle's circumference to its radius. That ratio leads to the union of coherence and decoherence in the "Tau Identity." The Tau Identity brings back into visible finiteness both the infinite number of radiuses in the invisible circle that surrounds the base of a pyramid and the invisible nothingness at its top.

In 1963, I faced the challenge of turning counterclockwise by 45 degrees a pyramidal drilling platform in Lake Maracaibo. Within topography, I decided to calculate an inverse intersection. The two surveyors whose azimuthal angles controlled the center of the circle that contained the squared platform told me later that my two-hour calculation could be replaced by measuring (on the circle around the square) the azimuthal angles of a flagpole installed in the new location of anyone of its four legs-before freeing the aluminum platform tied to anchored floating cranes. That experience shows how ancient Egyptians kept track of the smaller circles and squares that chase the nothingness at the top of any pyramid.

The pyramidal turnaround-from the squared-base-first-attention on the ground, to the infinite radiuses of its enveloping-invisible-circle-second-attention and the smaller circles that pursue nothingness on the tip of any pyramidion, into the Third-Attention that meets a renewed squared visibility on the Cartesian plane-remains ignored.

Cassella (2018a) reiterated that collapsing to zero the radius of a unitary circle centered in the origin of the Cartesian plane affirms the vertical axis of imaginary numbers in the complex plane.

As is customary, the horizontal axis (in blue) shows real numbers. Figure 3 also restates that complex numbers (the blocks of the Great Pyramid and a reflex of the Third Attention) result from adding real to imaginary tenets; the cosine (in blue) to the sine (in red) of the theta angle shown there; or the first to the second attention. In figure 3, Euler Identity and quantum coherence go with the red upper semicircle; whereas the whole circle (in light green) reflects the union of coherence and decoherence in the Tau Identity and the Third Attention.

Quantum coherence (Greek Pi) culminates in Euler Identity, the Al-'Isrã voyage of Muhammad from Mecca to the Farthest Mosque, Coatlquetzal's journey to Venus, and Martin Luther's vision about Christ's Omnipresence (infinity-Ubiquity) and Consubstantiation (nothingness-Coincidence). Quantum decoherence (Tau, or twice-Greek-Pi) welcomes the return of Muhammad to Mecca's Black Stone through his Wal-Mi'rãj journey, Quetzalcoatl's return with the secret of progress, the Tau Identity, and Transubstantiation in the Consecrated Host that becomes Christ. Martin Luther emphasized the principles of quantum computing within the second attention. However, the criticism of his "unreal Consubstantiation" (Cassella, 2018c) separated Luther from the "Collegio Romano"; and Rome. 


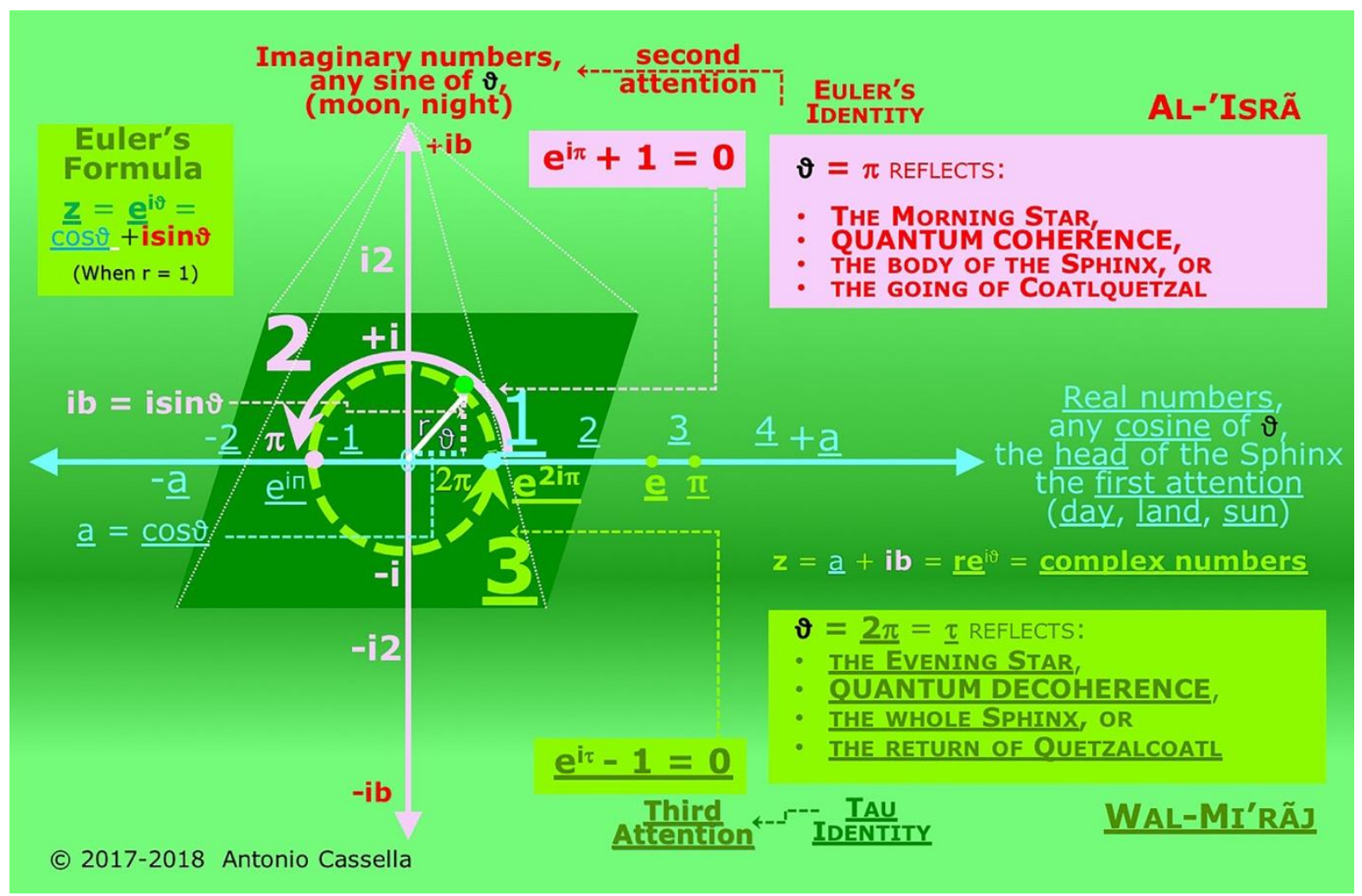

Figure 3. Comparing Euler Identity with the Tau Identity

\subsection{The Marriage of Infinity and Nothingness in the Return of the Prophet to Mecca}

The autistic principles behind faithful repetition ally with the creative principles that Martin Luther attached to the marriage of infinity with nothingness. That alliance marks the change from the going voyage of Muhammad, within the second attention, into his returning voyage with the Third Attention. It also marks the passage of Euler Identity into the Tau Identity (figure 3); Quetzalcoatl's return with the secret of the Third Attention; and the cooperation between autistic spacetime and artistic hyperspace implied by Gandhi's nonviolence.

The previous considerations follow:

a) Perner's (1991) findings that nonretarded autistics surpassed normal controls in Zaitchik's Photo Test (Zaitchik, 1990), based on linking true representations of the other (classical meta-representation in spacetime);

b) Baron-Cohen's (1995) observation that autistics fail tasks based on linking true with false representations (quantum meta-representation in hyperspace);

c) the discovery by Povinelli, Landau, and Perilloux (1996) that normal six-and-a-half-year-olds pass false belief and Proper Self - a test based on linking true representations of the self (again, meta-representation in spacetime);

d) the research of Cassella (1997, 2000), that high-functioning autistics will pass Proper Self;

e) Alfonso Caramazza's telling me in 1996 that Proper Self reflects a necessary and insufficient condition to pass false-belief tasks in hyperspace (Caramazza, 1994); and

f) the union of the spacetime principles spared in autistics with the hyperspace principles impaired in them

(Cassella, 2000, 2002a, 2002b, 2011, 2013, 2018c, 2018d)—or the logos heuristics.

\subsection{The Principles of the Logos Heuristics}

In figure 4, the logos heuristics engages my hypothesis that the Third Attention (3) combines the second attention (2) with the first attention (1):

- In $99 \%$ of us, the first attention (1) includes the autistics (1\%) that think of what they see; and in 1\%, the mad that see what they think of;

- the second attention (2) embraces autism and schizophrenia simultaneously in the humans (98\%) that empower the quantum malice that preys on others or the grace that prays for others; and

- the Third Attention (3) leads Gabriel (the Messenger of God) and Michael (our Guardian Angel) into defeating the devils that cut slyly our wings before inviting us to fly from a bridge. 


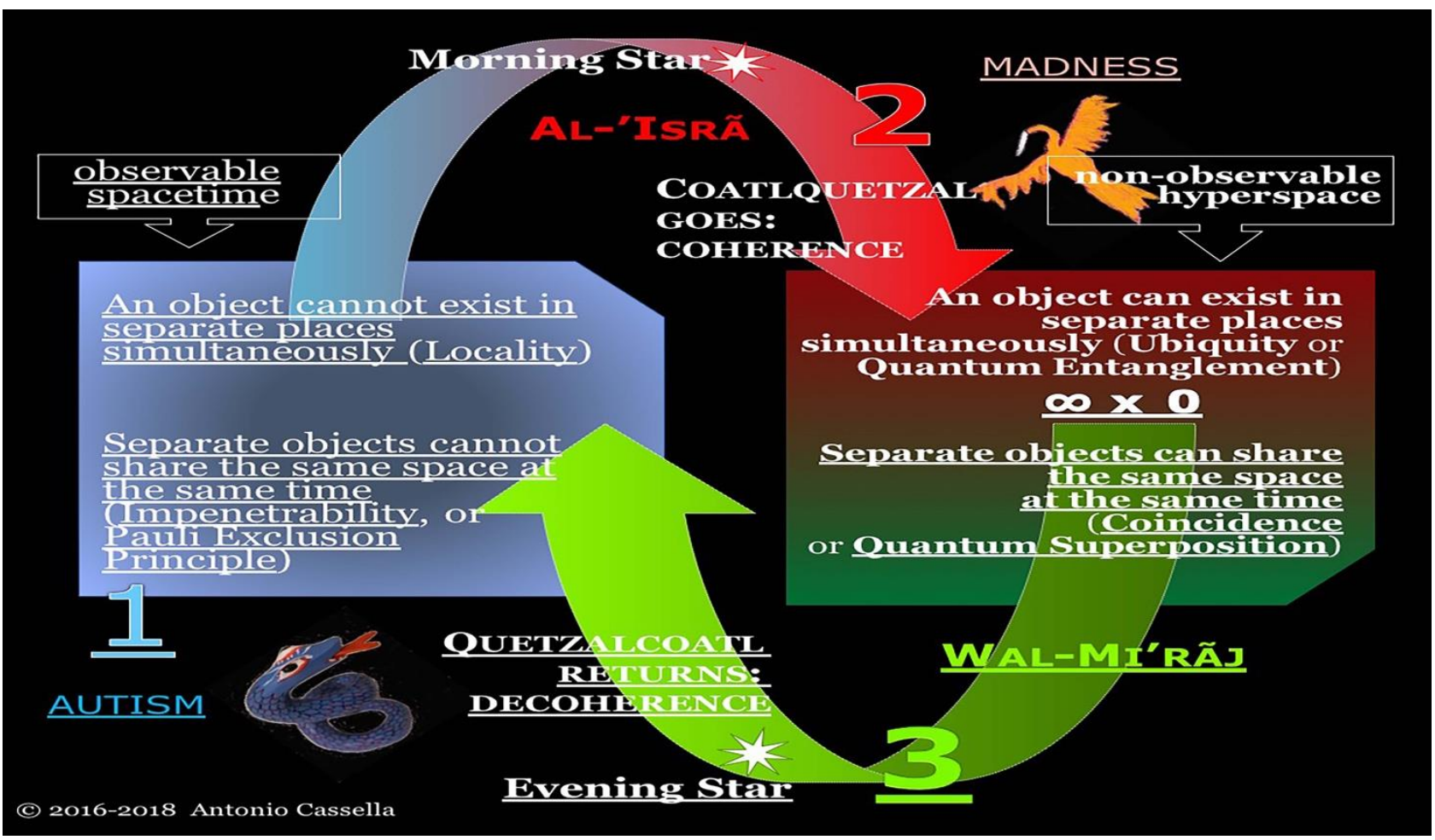

Figure 4. The union of the principles of the first attention with the principles of the second attention

In spite of Deborah Zaitchik's indication to me in 2002 (by phone) that the principles of spacetime contradict the principles of hyperspace, the first and the second attention may complement each other.

Past articles by Cassella (2017b, 2018a, and 2018b) stressed that in front of a red or green traffic light, our first attention forces us to stop or go; before a yellow traffic light, our second attention may side with the Devil in accelerating our car; or with Gabriel and Michael in slowing our car down; and our balancing Third Attention will follow the Virgin of Guadalupe in stopping our car before a green light-if a competing driver crossed our way.

The Great Mother (Inanna-Ishtar-QueenOfHeaven-Astarte-Devi-Durga-Kali-Parvati-Lakshmi-Saraswati-Aphrodite, Venus-Athena-Artemis-Diana, Hsiwangmu-Seowangmo-Seiobo-Guanyin-Longmu, VirginMary-Coatlicue-Guadalupe, MaríaLionza-Eywa) illustrates the grace of our artistic cognitive mother: "Quantum Computing."

Unlike the classical rigidity of Hamlet's autistic mother (Queen Gertrude) and the quantum malice of his uncle Claudius, maternal grace in the cerebellar second attention may:

a) enrich the rigidity of the father (for example, the literal interpretation of any Sacred Text);

b) introduce a new scheme into the autistic world dreamed by Darwin;

c) follow Sita in resisting the diabolical Ravana; and

d) favor the Third Attention in the return of Sita to her world with the heroic Rama.

Since the schizophrenic side of Hamlet cannot kill Claudius ("to be") in Act I, nor can his autistic side believe he is innocent ("not to be") too early, the simultaneously autistic and schizophrenic Prince of Denmark ("to be, or not to be") cannot marry his fiancé Ophelia—who goes mad in Act IV. The ambiguity in "To be and not to be" has funded script writers since the Roman Plautus wrote "Miles Gloriosus." Fortunately, most families thrive on tragicomic ambiguity.

\subsection{The Principles of the Logos Heuristics in Leonardo da Vinci’s Natività}

Figure 5 allegorizes the union of fatherly firmness (Joseph and the first attention) with motherly love (Mary and the second attention) that re-creates progress (Jesus and the Third Attention).

In expanding the historical testimony of Giorgio Vasari (1550) and the Anonimo Gaddiano (1893), I will recall Cassella's (2016) reasons for keeping "La Natività" ("Nativity Scene") as an example of Leonardo's unification of the second with the first attention:

The archangels Gabriel and Michael are located simultaneously inside and outside the animal shed in which Jesus was born (Omnipresence and quantum entanglement); and the feet of both archangels and the cloud share the same space at the same time (Consubstantiation and quantum superposition). 


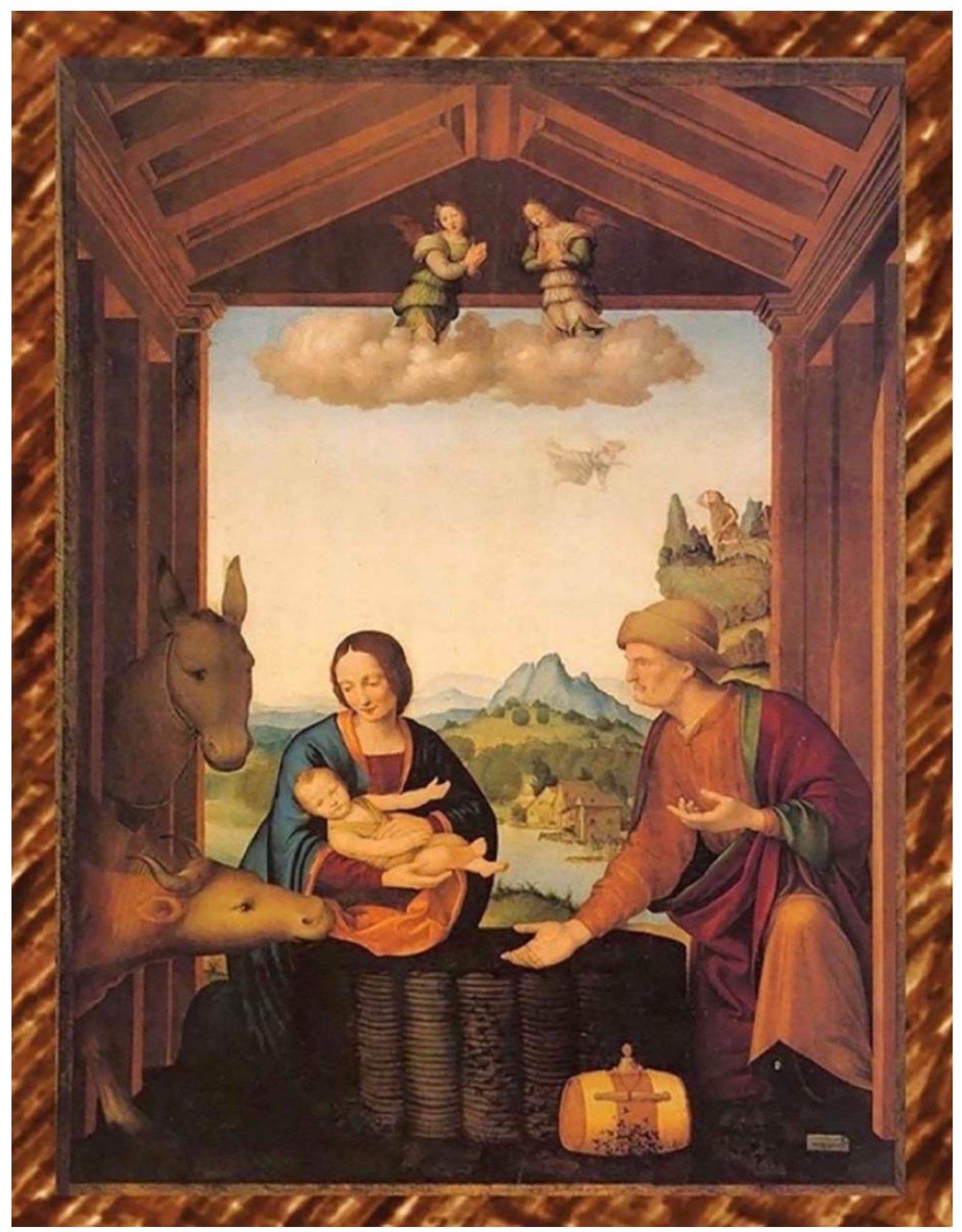

Figure 5. Leonardo's Nativity Scene ${ }^{3}$

Leonardo's Natività celebrates Ubiquity and Coincidence, which the Council of Trent abandoned with Luther in the $16^{\text {th }}$ century CE. Martin Luther preached that Christ's Omnipresence (Ubiquity) and Consubstantiation (Coincidence) empower each other: Without Gabriel and Michael, the cloud would stay outside; and without the cloud, the archangels would fly inside. The principle of Locality nourishes the contours of Joseph, Mary, Jesus, the two archangels, animals, plants, and the mountains behind them; and the principle of Impenetrability (or Pauli's exclusion principle) helps Jesus stay on Mary's hands.

\subsection{The Lesson Hidden by Leonardo in the Mural Battaglia di Anghiari}

The first attention helps us defeat the enemies that menace our family. Although Joseph follows peace, he also represents our impulse to keep strangers out. That impulse led Florence to win over Milan in the Battle of Anghiari, centered by Leonardo da Vinci in his Fight for the Standard (figure 6).

\footnotetext{
${ }^{3}$ The Diocese of Tortona (AL, Italy) authorized the reproduction of "La Natività".
} 


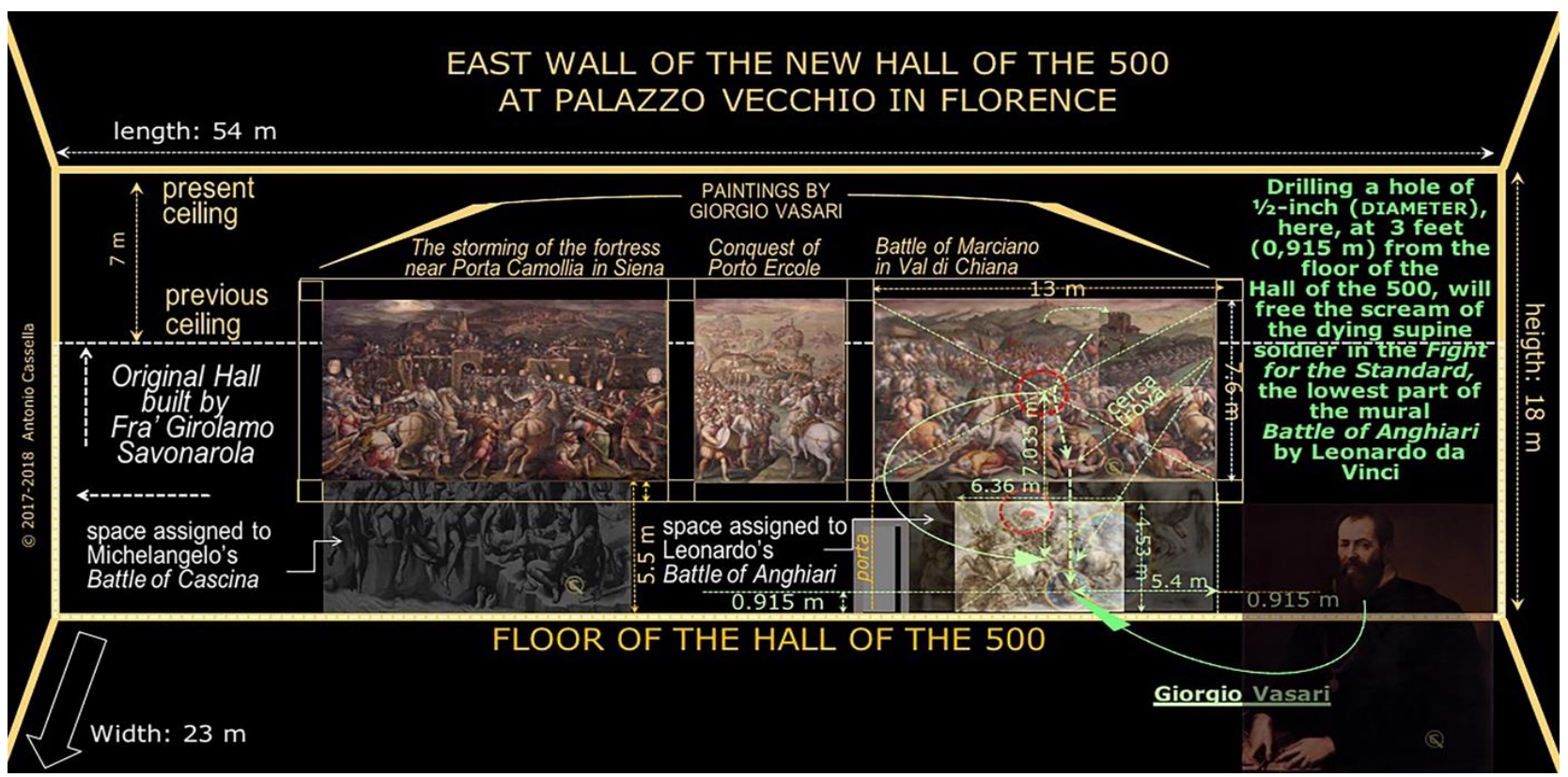

Figure 6. Location of Leonardo's Fight for the Standard in the "Hall of the 500" at Florence's Palazzo Vecchio

Cassella's (2017b) article in the IJSSS locates the center of the Fight for the Standard 7.035 meters below the center of Vasari's Battle of Marciano, in the Hall of the 500, at Florence's Palazzo Vecchio.

If a hole were drilled at the height of 0.915 meters from the floor, on the vertical that crosses the screaming soldier on the ground of the Battle of Marciano, then the laying soldier of Leonardo's Fight for the Standard would also release his scream.

\subsection{The Readjustment of Cerebral Beta Waves Provided by Cerebellar Microcomplexes}

Unlike the scream of fear guided by beta brainwaves in the cerebral structures that ignore the cerebellar readjustment of fixed motor schemata, the alpha-theta waves of our cerebellar microcomplexes may escape angry delta waves (figure 7).

The readjustment that prevents an own-goal and scores a goal in FIFA's World Cup is an example (figure 7) of the relationship (Cassella, 2018b) between cerebral columns (classical computing) and the columns of cerebellar microcomplexes (quantum computing). Another example is Western readers' ability to read an upside-down paper.

In that case, users of the Latin alphabet would not confuse the polyvalent letter "b" with "d," "q," or "p" because they attach "b" (the Greek "bet") to any vowel (for example, the Latin "a," or the Greek "alpha"), whose meaning does not change under any rotation. Thus, the letter "a" equals the first attention; the letter "b," Euler Identity and the second attention; and the "alphabet" behind the syllables "ba," "da," "pa," and "qa", denotes the Tau Identity and the Third Attention.

Similarly, nonautistics' cerebellar capacity to occupy the place of an interlocutor without leaving their place allows them to exchange suitably the pronoun "me" with the pronoun "you." For instance, to Jane's unassuming presentation, "You Tarzan, me Jane," cerebellar quantum computing in Tarzan answered, "Me Tarzan, you Jane." The nonautistic Ape-Man never called himself "Youtarzan"; or his sweetheart, "Mejane."

Beyond the cerebellar readjustment of cerebral motor schemata (shown in figure 7), the contextual use of pronouns implies that the first attention and classical computing in each cerebral hemisphere-and in the two hemispheres as well - undergo a quantum balancing act. Cassella (2018b) follows Ito's (2011) and the failure of autistics to engage pronouns properly in showing that balance in cerebral walking, breathing, and talking is directed by forward and inverse cerebellar dynamics. These dynamics are performed by 5000 cerebellar microcomplexes - the keepers of the quantum computing attached to Muhammad's Al-'Isrã and Wal-Mi'rãj voyage.

Because autistics cannot embrace quantum computing, their cerebrum cannot abandon the solar disc around Vishnu; nor can they disintegrate traditional interpretations through Euler's Identity, Shiva's trident, and Muhammad's Al-'Isrã journey. Moreover, unmedicated schizophrenics cannot find the Tau Identity, Brahma, the return of Quetzalcoatl, and Muhammad's Wal-Mi'rãj journey.

As explained in Cassella (2018b), autistics show difficulties in embracing quantum coherence, Masao Ito's (2011) 
Stabilization, or the Long-Term Potentiation that feeds competing possibilities of being to cerebellar Purkinje cells (figure 7). Because of that limitation, autistics follow unmedicated schizophrenics in their inability to grasp the convergence attached to Ito's Control, Long-Term Depression, or quantum decoherence.

Unlike Prince Calaf in Turandot's plot, autistics and schizophrenics cannot sing the decoherence-word "vincerò" ("I will win"), immortalized by the tenor Luciano Pavarotti.

Calaf's love and his quantum ability to solve Turandot's riddles make him believe that that Chinese princess will marry him if she cannot guess his name before dawn. As with the servants of Turandot that are promised death if they do not expose suitably the unfamiliar name of the visiting Mongolian prince, the cerebellar Purkinje cells that stick to traditional conclusions are disinhibited.

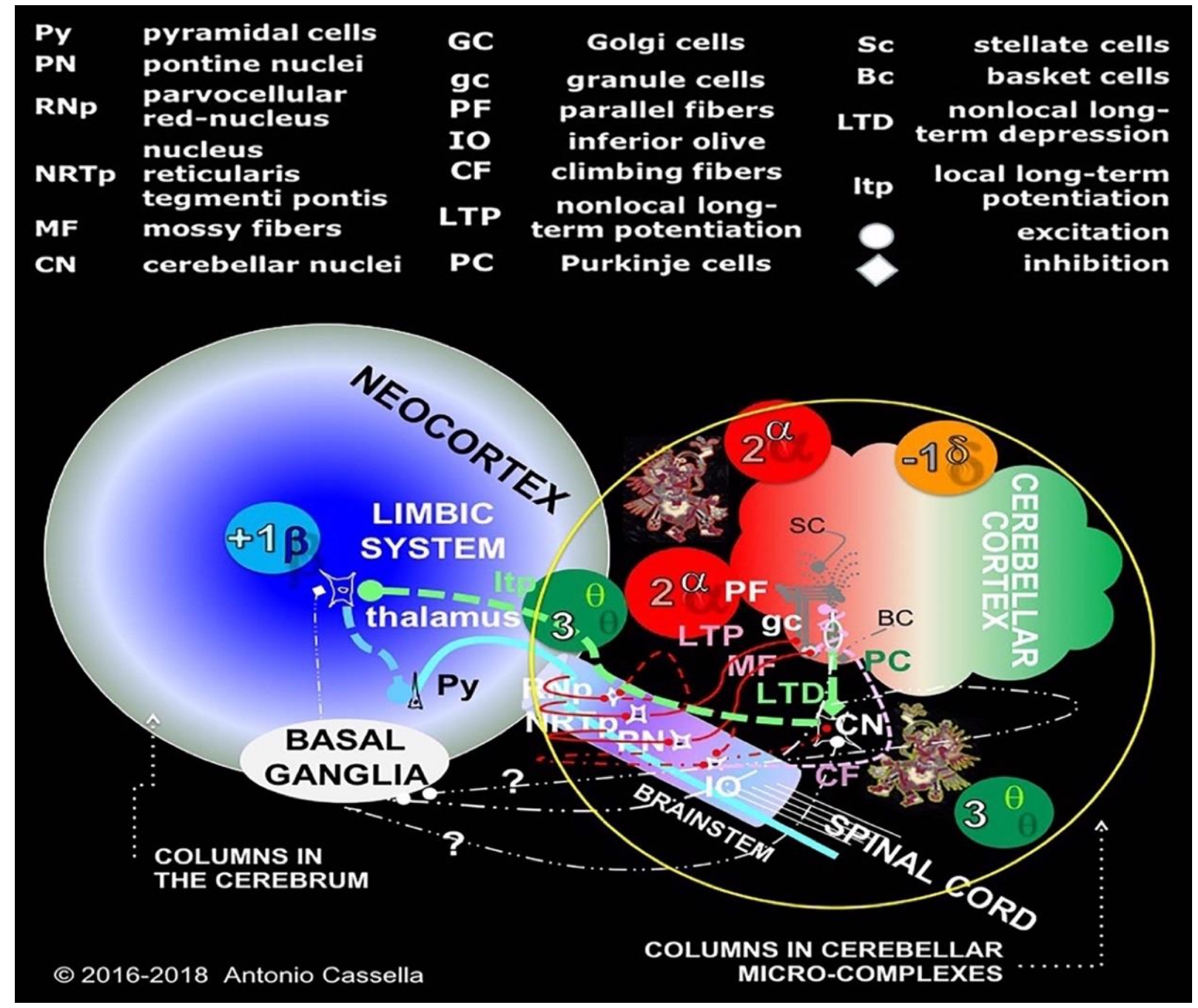

Figure 7. The readjusting action of alpha-coherence and theta-decoherence waves over beta and delta waves

By contrast, the Purkinje cells that reject familiar solutions will continue inhibiting the cerebellar nuclei that will behead Calaf if Turandot empowered her destructive second attention; or the nuclei that will marry him to Turandot if his love revived her Third Attention. Most admirers of Giacomo Puccini prefer the latter alternative.

Figure 7 shows that beta waves become first alpha waves in replacing Vishnu's solar disc with Shiva's trident, near angered delta waves; and then, theta waves and Brahma's exhalation. In reality, the Hindu Trimurti is enlivened when Devi switches Shiva's deadly trident with the harp of quantum decoherence.

Sadly, we cannot sing through the uncontaminated air that revived Buddha in the $6^{\text {th }}$ century BCE; Xuanzang, 13 centuries later, when he left China in reaching India and the secrets of Buddhism; and Bodhidharma, one century before Xuanzang, in reaching China from India to teach his path of meditation.

Contaminated air, however, could be revived in walking-breathing-talking meditation by directing Samatha-Memory-FirstAttention and Vipassana-Insight-SecondAttention into Metta-LovingKindness-ThirdAttention. 


\subsection{Main Variables of Climate Change}

In figure 8, I exhibit air contamination in the last 650000 years (Cassella, 2017a). Figure 8 also shows that, 125000 years ago, sea level was seven meters higher than today, in correspondence with a 3-degrees-Celsius higher temperature in the lower atmosphere.

Although the cause of climate changes may rest in a varying insolation (Milankovitch, 1992), sea-level will rise if the temperature of the lower atmosphere goes up; whatever the cause. In the past, the atmosphere became contaminated when its temperature went up; and its temperature went up whenever the atmosphere became contaminated: A dragon wakes up when the atmosphere picks up heat, methane, carbon dioxide, or nitrous oxides!

The air we breathe today is extremely contaminated (figure 8). Our recklessness will cause a marked rise in the average temperature of the lower atmosphere. Although they have grandchildren, most powerful leaders and their thoughtless supporters embrace happily the philosophy of "Après moi le déluge!"

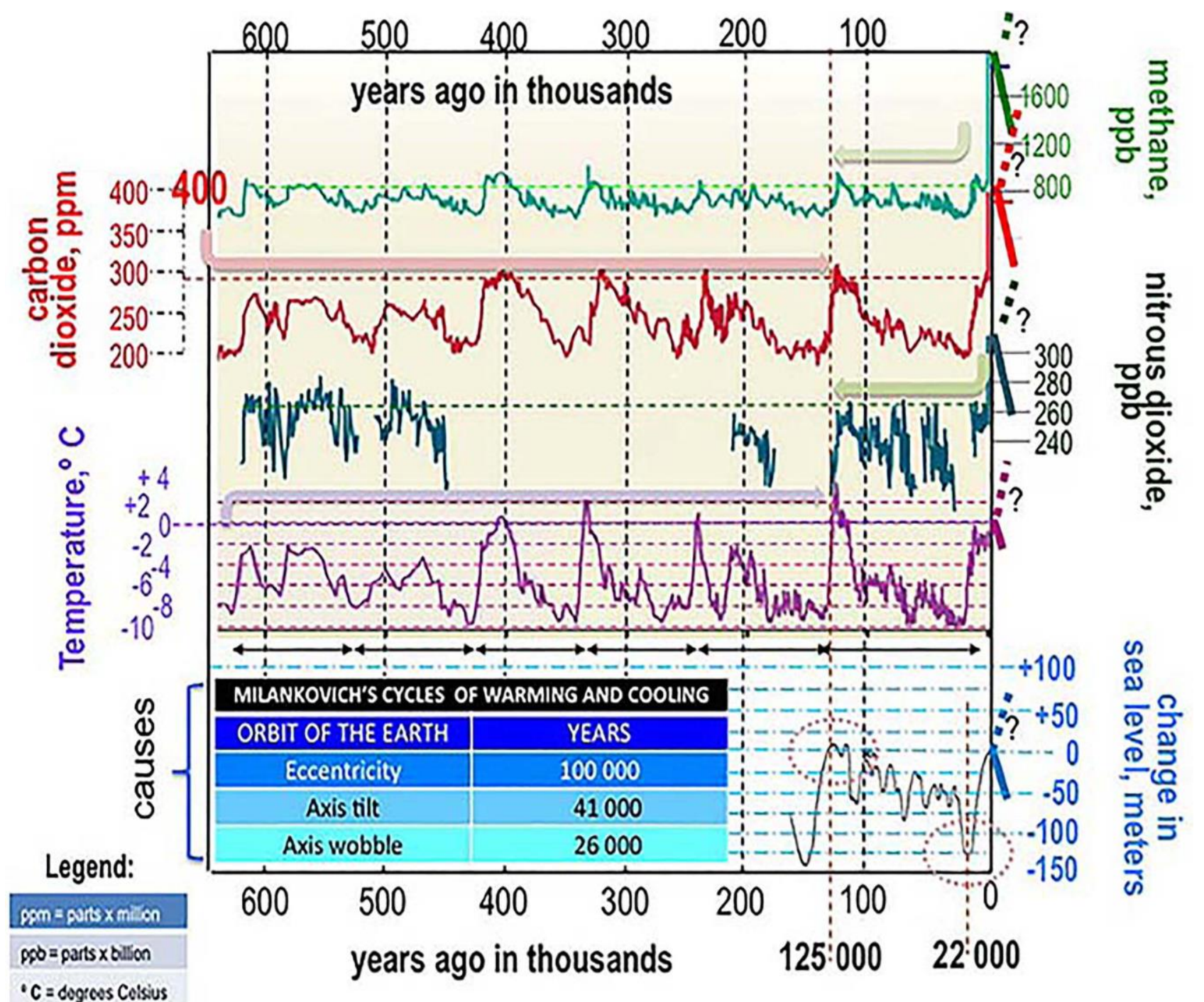

Figure 8. Key variables of climate change in the last 650000 years $^{4}$

If Milankovich were right (a hypothesis espoused by Hays, Imbrie, and Shackleton [1976]), and most leaders were as intelligent and incorruptible as St. Francis Xavier, the next 9000 years would bring in the wet monsoon into Nubia (Sudan) and Libya.

\footnotetext{
${ }^{4}$ The upper four graphs come from the 2007-report of the IPCC (Intergovernmental Panel on Climate Change). The variation of sea-level comes in its greatest part from NOAA (National Oceanic and Atmospheric Administration in the USA).
} 


\section{Discussion}

\subsection{The Incursions of Pharaoh Sneferu into Nubia and Libya at the Turn of the $27^{\text {th }}$ Century BCE}

Erosion in Giza's Sphinx points at a rainier prehistoric Egypt, in which kind rulers counted plentiful cattle. A drier climate or a subdued understanding may have dampened that abundance. At the turn of the $27^{\text {th }}$ century BCE, Pharaoh Sneferu organized raids into verdant Nubia and Libya before building the Meidum, Bent, and Red pyramids (Guillemette, 1997). The House of Thoth may have considered then that the unkind intelligence through which Sneferu assaulted successfully his neighbors could be put to a better use.

Perhaps the Head of the House of Thoth—-the vizier that served Sneferu—convinced his son, Prince Hemiunu, to serve an altruistic dream of Pharaoh Khufu:

Tell future generations to promote the reciprocal empowerment of classical and quantum computing (or the Third Attention) in women, children, nonhuman species, and even monsters.

Centuries later, the dream of saving humans' first-attention-conservation, second-attention-creativity, and Third-Attention-recreation was knit in the failure of the Sumerian King Gilgamesh (a metaphor for the conserving first attention) to save his savage friend Enkidu (the creative second attention in the "tree-of-knowledge"), and the "Tree-of-Life" (or the Third Attention).

\subsection{Gilgamesh's and Enkidu's Killing of the Monsters Humbaba and Gugalanna}

Figure 8 indicates that sea level climbed by 125 meters since the end of the last Ice Age. I assume that about 12000 years ago, a priestess in the Middle East (Göbekli Tepe? Jericho? El Faiyum?) noticed that sea level and air temperature had risen noticeably. At the turn of the $3^{\text {rd }}$ millennium BCE, however, male worriers may have buried matriarchy (Pagels, 1996). Three centuries later, sacred priestesses became the courtesans that corrupted the hairy Enkidu (a savage inhabitant of the woods around Sumerian Uruk).

Repentance in leaders that return to the fair use of quantum computing is, nonetheless, acceptable. For example, the first literary work in history, The Epic of Gilgamesh (Andrew, 1999), shows that the death of his friend Enkidu induced the repentance of Gilgamesh (a King of Uruk in the $27^{\text {th }}$ century BCE).

The story of Gilgamesh shows how an incensed Inanna - a good-looking aspect of the Goddess-Mother-asked an assembly of gods for bringing death to Enkidu (a metaphor for the crazy use of quantum computing). Enkidu had helped Gilgamesh kill Humbaba (the guardian of primeval forests) and Gugalanna, the monster she had freed in Uruk to stop the arrogance of its male worriers. After the death of Enkidu, Gilgamesh reached Utnapishtim, in seeking the plant of immortality.

The survivor of the first flood showed Gilgamesh how to find that plant in the bottom of the sea. Gilgamesh was successful; but his indulging use of water (another metaphor for the second attention), while returning to Uruk, invited a devious snake to steal the "Tree-of-Life." In his autistic attachment to routines, Gilgamesh had left behind the sober use of the "tree-of-knowledge" (Enkidu, quantum computing, and water) and neglected the Tree-of-Life-Third-Attention that had enlivened a cooler sea.

\subsection{The Warning Issued by Zechariah.}

The peak of global warming shown on the right of figure 8 hides the eventual loss of the Tree-of-Life that feeds progress: If the average temperature of the lower atmosphere increases by 2-3 degrees Celsius, extraordinary amounts of carbon dioxide (from the sea or the permafrost) and methane clathrates (the marine escapees of deep gas) may contaminate Earth's atmosphere.

As reported in Cassella (2017a), either intruding carbon dioxide or methane may alter the equilibrium between sulphur-fed bacteria and oxygen-fed bacteria in the depth of Earth's oceans (Ward, 2006). In the Permian Period, either outcome (linked to a concentration above $1500 \mathrm{ppm}$ of carbon dioxide in the atmosphere and a rise of eight degrees Celsius in its average lower temperature) destroyed the ozone shield and two-thirds of the biota.

\subsection{The Cognitive Degeneration Hidden in Uncreative Discourse.}

Besides the possibility that the ozone layer may vanish at the turn of the $21^{\text {st }}$ century, there are other reasons to believe that time is running short. The elimination of subjunctive tenses in our discourse, for example, shows that our minds are deteriorating too fast.

That fact is linked to the derisive comment "non azzecca un congiuntivo" ("he does not use the subjunctive"), expressed by mature Italians to denote the poverty of the fouled discourse of some teen-agers. Autistic beta and schizophrenic delta brainwaves do not ally easily today — as they did in Khufu's time — with artistic alpha and theta discernments (figure 7). 
My observation about the erosion of our cognitive riches also follows:

The global increase of autistics and schizophrenics; the spread of terrorism; the violation of thousand school-girls; the killing of elephants, vultures, and lions; the travesty of democracy through fraudulent elections; the rise of dictators protected by their capability to unleash destructive nuclear weapons on any city on Earth; our desire to drive bigger cars; our love for digital games devoid of spontaneous dialogues; unintelligent artificial intelligence; our envy; our rage; and our actions to prevail over our competitors - as did Florence in the $15^{\text {th }}$-century-CE "Battle of Anghiari."

\subsection{The Lesson Hidden in Leonardo's Fight for the Standard and Nativity Scene}

We have lost track of the social values hidden by Leonardo da Vinci in the vanished central scene of his Battle of Anghiari: The Fight for the Standard (shown in figures 6 and 9).

More than delta-wave brainstorms in the rage of the Florentines, Leonardo highlighted in his mural the theta-driven courage that animated the avatars of the Milanese (the "Condottiero" Niccolò Piccinino with the red hat and his son Francesco at his right).

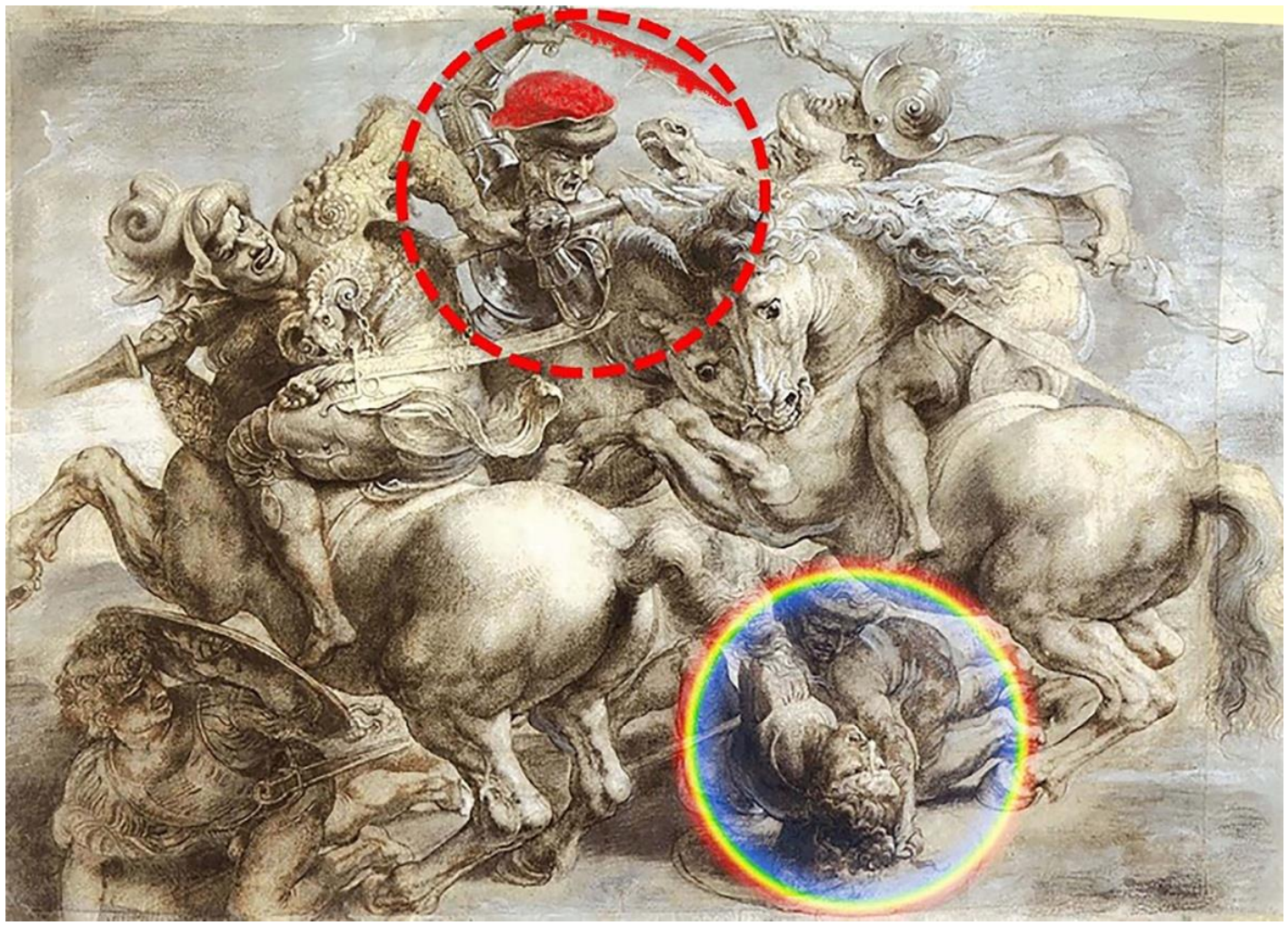

Figure 9. The Fight for the Standard by Leonardo da Vinci

Leonardo's coherence sided with both Milan and Florence; and his artistic decoherence, with future spectators.

The elegance of the design of that Florentine artist was lost on the rightists that gathered in Charleston (South Carolina) in 2017; and in the leftists that opposed them. Fortunately, Leonardo also expressed the nonlogical union of classical and quantum computing (figure 4) in the Nativity Scene (figure 5).

Freeing the Fight for the Standard (Lotta per lo Stendardo) from the opacity under Vasari's Battaglia di Marciano in Florence's "Hall of the 500" at Palazzo Vecchio and recognizing Leonardo's hand in La Natività kept in the church of "Santa María dei Canali" at Tortona will favour the alliance (figure 4) of the principles of the first with the principles of the second attention - into the Third Attention of families (figure 5), cultures, and global society.

The Wal-Mi'rãj trip of Muhammad, the return of Quetzalcoatl to Teotihuacan, Greek Tau in the complex plane, the Tau Identity (figure 3), and the ratio (in the vicinity of Tau) between the perimeter of the base and the height of five major pyramids in Egypt point all at the opportunity of re-directing the power of quantum computing.

Before World War II, a Latvian emigrant hid that secret in his Floridian "Coral Castle." Ed Leedskalnin also showed that building the Sphinx and Khufu's pyramid was not so difficult as it may seem at first sight. 


\subsection{The Secret Enclosed in the Construction of Coral Castle}

Figure 10 highlights the fact that 125000 years ago the oolites that lived in the space occupied by today's Miami built the limestone quarried by Ed Leedskalnin.

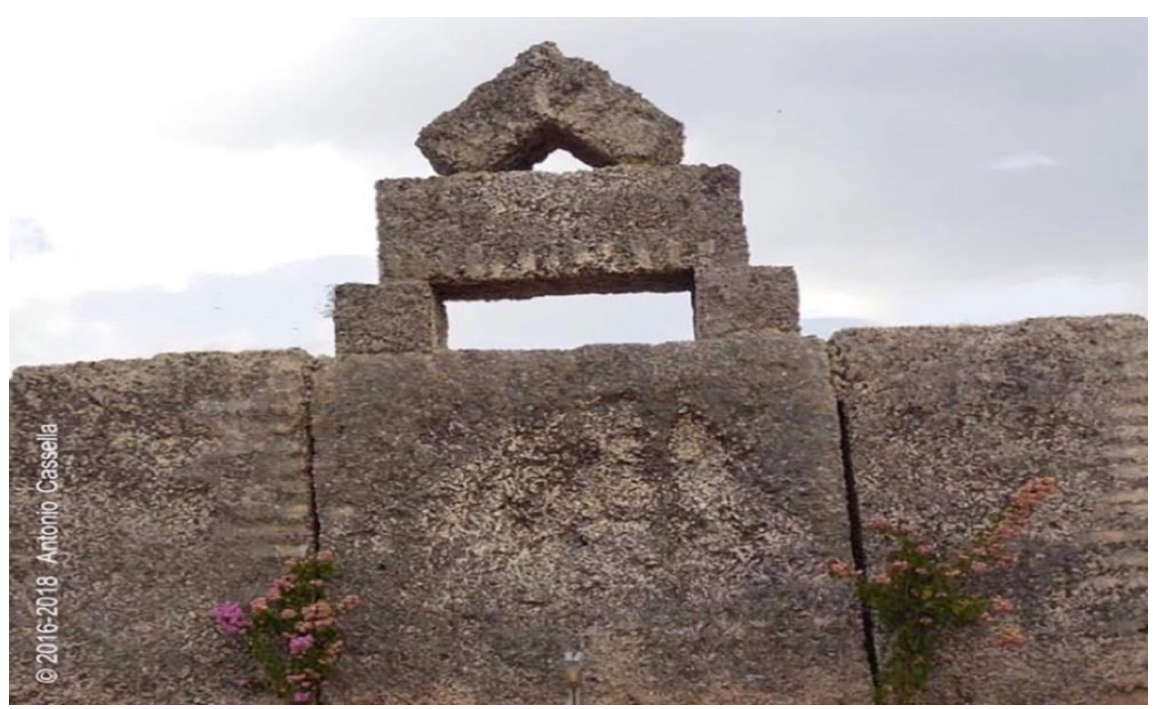

Figure 10. A mysterious structure built by Ed Leedskalnin in Southern Florida

During a working span of about 30 years, Ed quarried about 1000 tons of limestone to build "Coral Castle," south-west of Miami. In line with his productivity (2.77 tons/month), if ancient Egyptians had iron tools (they did not), 8625 workers would have excavated in 20 years the 5.75 million tons of limestone in Khufu's pyramid at Giza.

When Ed was asked about how he assembled heavy blocks of limestone without the help of machinery, he answered that he followed in darkness the methods used under the sun by ancient Egyptians.

Forty-five centuries ago, there were no machinery with the proportional band of the first-attention (as in the compressor of an air conditioner that shuts down at the error predicated by a room-temperature of 23 degrees Celsius and starts again at the error enclosed in a 27-degree room-temperature), a reset linked to the integral control that eliminates the error in the longer term (the second attention), and the derivative control (the Third Attention) that anticipates future errors.

Still, Ed Leedskalnin and Pharaoh Khufu embraced the derivative mode of control in following a dream: Avoid global chaos by taking notice of the natural and humane ways of the Third Attention.

Ed's particular message can be read in the structure of Coral Castle shown at the top of figure 10. The two columns on the wall separate the autistic from the schizophrenic facet of the mind. That separation can be bridged by the second attention, which may destroy a castle or sustain the pointed-arch of the Third Attention.

While living, Ed Leedskalnin found his Third Attention in the derivative that adds reset (quantum computing) to proportional band (classical computing). Will we follow Derivative Control and the Third Attention or continue exploiting the deceptive power of the Devil-Ahriman-Reset in the void between autism and schizophrenia?

Under the four-piece structure built by Ed, one may observe the silhouette of a tree (or the Archangel Gabriel?). Trees are a memento of the rain that, if global warming became global cooling, would wet again the deserts between the Tropic of Capricorn and the Tropic of Cancer.

In relation to Gabriel, besides hindering the malevolent Ahriman, he guided a Neanderthal artist.

\subsection{The Secret Enclosed in Gorham's Crossing at Gibraltar}

Ed Leedskalnin, Khufu 45 centuries before him, and ancient priestesses 65 centuries before Khufu realized that only the rise of the Third-Attention-Derivative before dying retains enduring social significance. The lives and dreams of Yuenü, Martin Luther, Inés de-la-Cruz, Amelia Earhart, Mahatma Gandhi, Rosa Parks, Mother Teresa, and Martin Luther King Jr. are key examples of this truth.

During 360 centuries of hypothetical matriarchy, sober "women-of-knowledge" (Castaneda, 1972) dreamed the Third Attention hidden by sober "men-of-knowledge" in Giza's Sphinx, the Great Pyramid, and Coral Castle. The hypothesis about humans' early awareness of the Third Attention (Cassella, 2016) rests on a crossing (figure 11) cut in Gorham's cave at Gibraltar (Rodríguez-Vidal et al., 2014). 


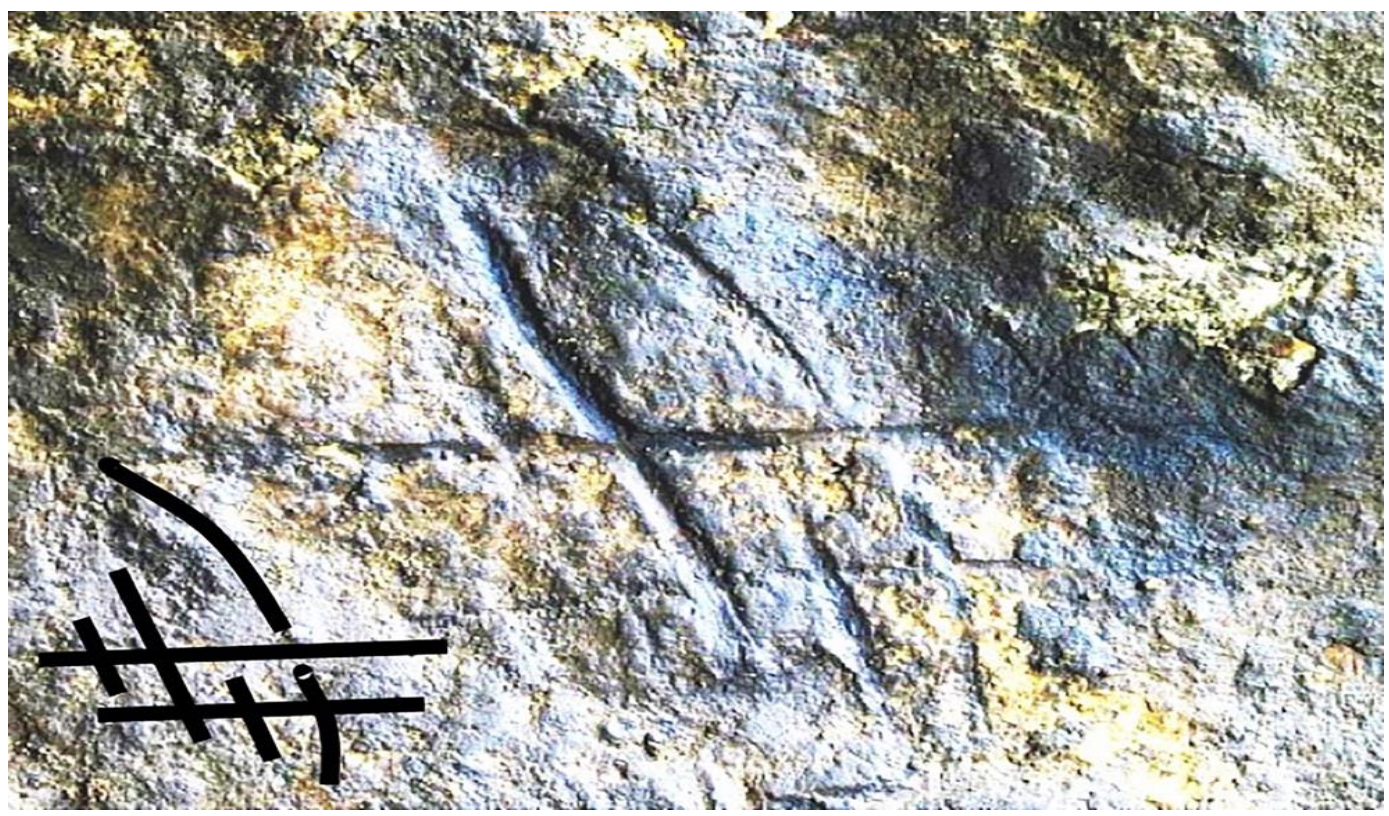

Figure 11. The emblematic drawing found in Gorham's Cave at Gibraltar ${ }^{5}$

My putative interpretation (bottom left) of the symbolic drawing carved in Gorham's Cave at Gibraltar about 40000 years ago denotes: classical computing in the three vertical lines from left to right; quantum coherence in the upper horizontal tracing (which tenses the bow of quantum computing from right to left); and quantum decoherence in the lower horizontal line, which releases tension through humanistic recreation.

Possibly, primeval "women-of-knowledge" also detected that:

a) Most stars keep the same configuration in relation to each other-as in the stability of the asterism of a reclined lioness, or a standing male-lion, in our Leo constellation;

b) the celestial lioness looks at the star we call now Sirius;

c) the Northern Cross (part of Cygnus) opposes the asterism known as Orion Belt; and

d) the Milky Way dances between Orion and Cygnus.

Ancient Egyptians too may have recognized the stability of the crossing of two arches in the Northern Cross and of one arch in the Orion Belt.

\subsection{The Coherent Decoherence of the Cygnus Correlation}

The astronomer Anthony Fairall (1999) indicated that Bauval's and Gilbert's (1994) relationship between the Sphinx and the arch of the Orion Belt is valid only if one reverses the north-south direction without inverting the east-west direction - a topographic anomaly at present. Fairall's observation bolsters Collins' (2007) Cygnus Correlation, described in the background.

Collins also proposed (figure 12) that the top of the Gebel-Gibli hill (south-east of Khafre's pyramid) welcomes the southern vertex of a right-angled triangle sized:

a) 3 units in its south-to-north shorter side;

b) 4 units in the east-to-west side, which crosses the peak of Khufu's Great Pyramid; and

c) 5 units in the hypothenuse that returns to Gebel Gibli, after crossing the peak of Khafre's Pyramid.

Beyond Collins' Cygnus Correlation, I include in figure 12:

a) the arch-circle that hosts the pyramids of Khufu/Delta-Cygni, Khafre/Gamma-Cygni, and Menkaure/Epsilon-Cygni:

c) the coincidence of Albireo, the star at the lower end of the greater beam of the Northern Cross, with the top of Gebel Ghibli;

b) the alignment with Deneb of the longer cathetus of the right triangle 3-4-5; and

d) the arch-circle that hosts Deneb, Gamma-Cygni/Khafre's-Pyramid, and Gebel-Gibli/Albireo.

${ }^{5}$ The picture of Gorham's crossing was taken by Rodríguez-Vidal et al (2014). 


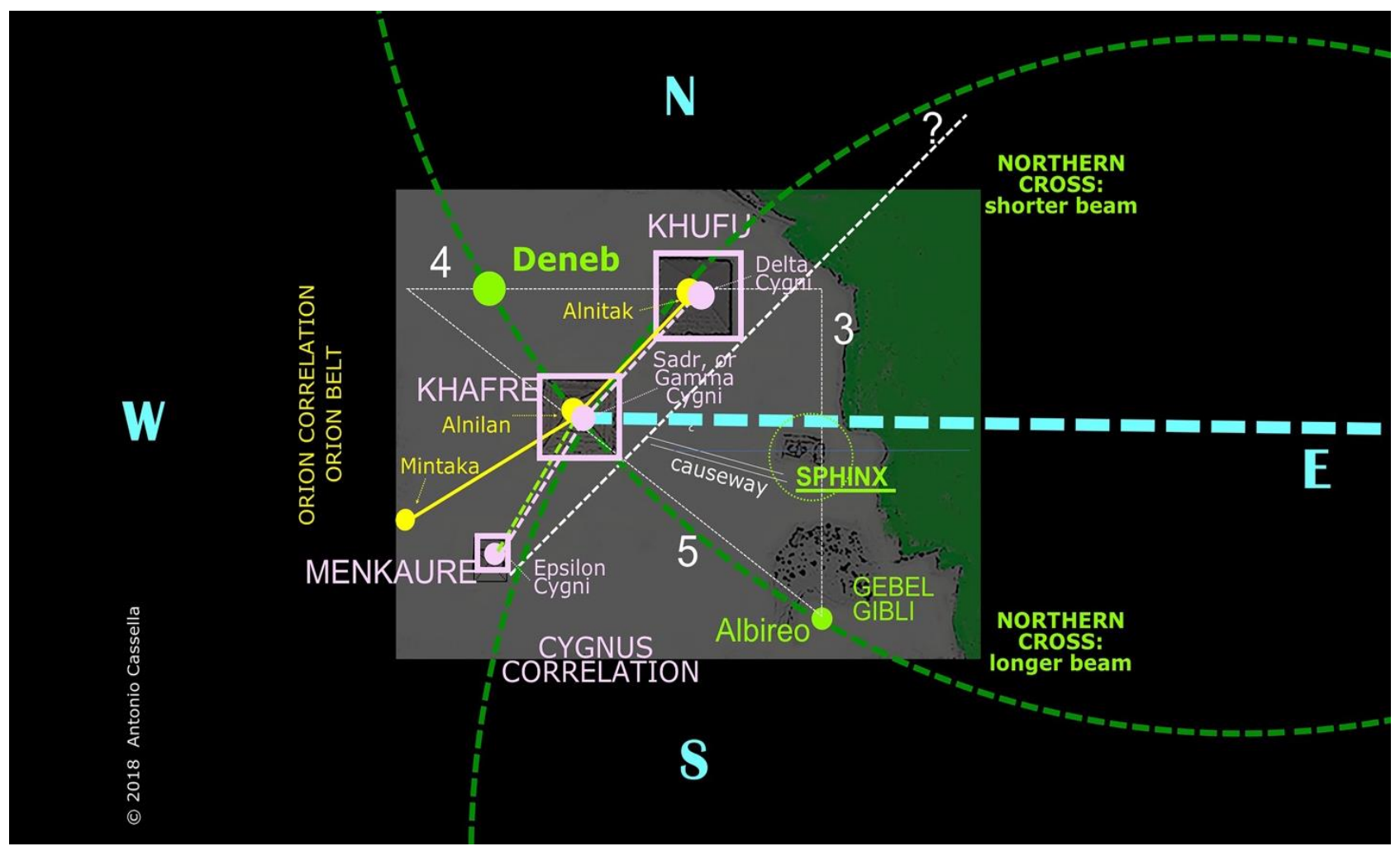

Figure 12. Comparing the Cygnus Correlation with the Orion Correlation

\subsection{The Purposefulness Hidden in the Re-carving of the Sphinx and in the Construction of the Great Pyramid}

I wrote in the background that Egyptians used the right-triangle 3-4-5 to trace the two diagonals of the squared base of their pyramids.

If the 280 Egyptian royal cubits in the height of the Great Pyramid matched the number 4, the number 3 would correspond to 210 cubits. Instead of measuring 210 and 280 cubits, however, the catheti of the right triangle chosen by Hemiunu and Khufu to mark the position of the vertex of the Great Pyramid agree with 220 and 280 cubits. The excess of 10 cubits in the shorter cathetus enhances the stability of the Great Pyramid and produces 6.286 (in the vicinity of $2 \pi$, or Tau $[\tau])$ when we divide the perimeter of the base of the Great Pyramid ( $440 \times 4=1760$ cubits) by its original height (280 cubits).

The latter result is reinforced by looking at the dimensions of the Sphinx. The lying Sphinx-20.25-meter high $\mathrm{x}$ 73-meter long - matches the shape of Leo's asterism, which we equate with an erect lion. The shorter rectangle corresponding to the body of an erect Sphinx would be 52.6-meter long and 11-meter high. If we divide its perimeter by the height of today's Sphinx we would obtain 6.28 - resembling the irrational and transcendental value of Greek Tau.

In re-carving the monstrous head of Giza's lioness, Hemiunu and Khufu froze the hypothetical knowledge accumulated by the House of Thoth about the Third Attention that re-directs autistic rationality, schizophrenic irrationality, and destructive ambition into a universal harmony.

\subsection{Complementing Pythagoras' Rational Vision of Universal Harmony}

I assume that sages in the House of Thoth valued the harmony that merges rational numbers with the infinite nothingness that enlivens Greek Tau. However, the Pythagorean comma in Pythagoras' musical scale indicates that Hemiunu's and Khufu's message may not have reached the Egyptians that hosted Pythagoras in the $6^{\text {th }}$ century BCE.

In modern times, composers and manufacturers of musical instruments have confronted Pythagoras' musical scale with the equal-tempered scale, in which 12 irrational intervals, taken as the twelfth root of number $2(1.059463 \ldots$ to infinite nothingness) vary by 100 cents. In the equal-tempered scale, rational clues point only at the unison $\left(2^{0 / 12}, 1\right.$, or 0 cents $)$ and the end of the octave $\left(2^{12 / 12}, 2\right.$, or 1200 cents).

Perhaps Pythagoras never perceived the meeting of rationality and irrationality in music. Unlike Pythagoras' rational inflexibility, flexible rigidity in Rossini's The-Thieving-Magpie (La-Gazza-Ladra), Mozart's Symphony-\#40, and Beethoven's Symphony-\#9 reflects the harmony of the Third Attention hidden in music and Giza's monuments. 


\subsection{The Harmony behind the Disposition of the Monuments of Giza}

As the greatest of the five (sages?) of the House of Thoth, possibly Prince Hemiunu supported Khufu's master plan involving Giza's monuments and the nocturnal sky above them. The hypothesis that Hemiunu and Khufu connected Giza's Pyramids, the Sphinx, and The Nile with a few constellations and the Milky Way led me to an insight: $I$ superimposed, rotated, and shrank a view of the night sky in the northern hemisphere on an aerial view of Cairo and The Lower Nile. I sought the coincidence between the alignment of Khufu's, Khafre's, and Menkaure's pyramids and the wing stars of the Cygnus constellation.

The Cygnus Correlation (Collins, 2007), my surveying exposure, and my hunch led to tracing two primary triangulation-circles, with 11.25-mile and 9-mile radii respectively (shown in figure 13).

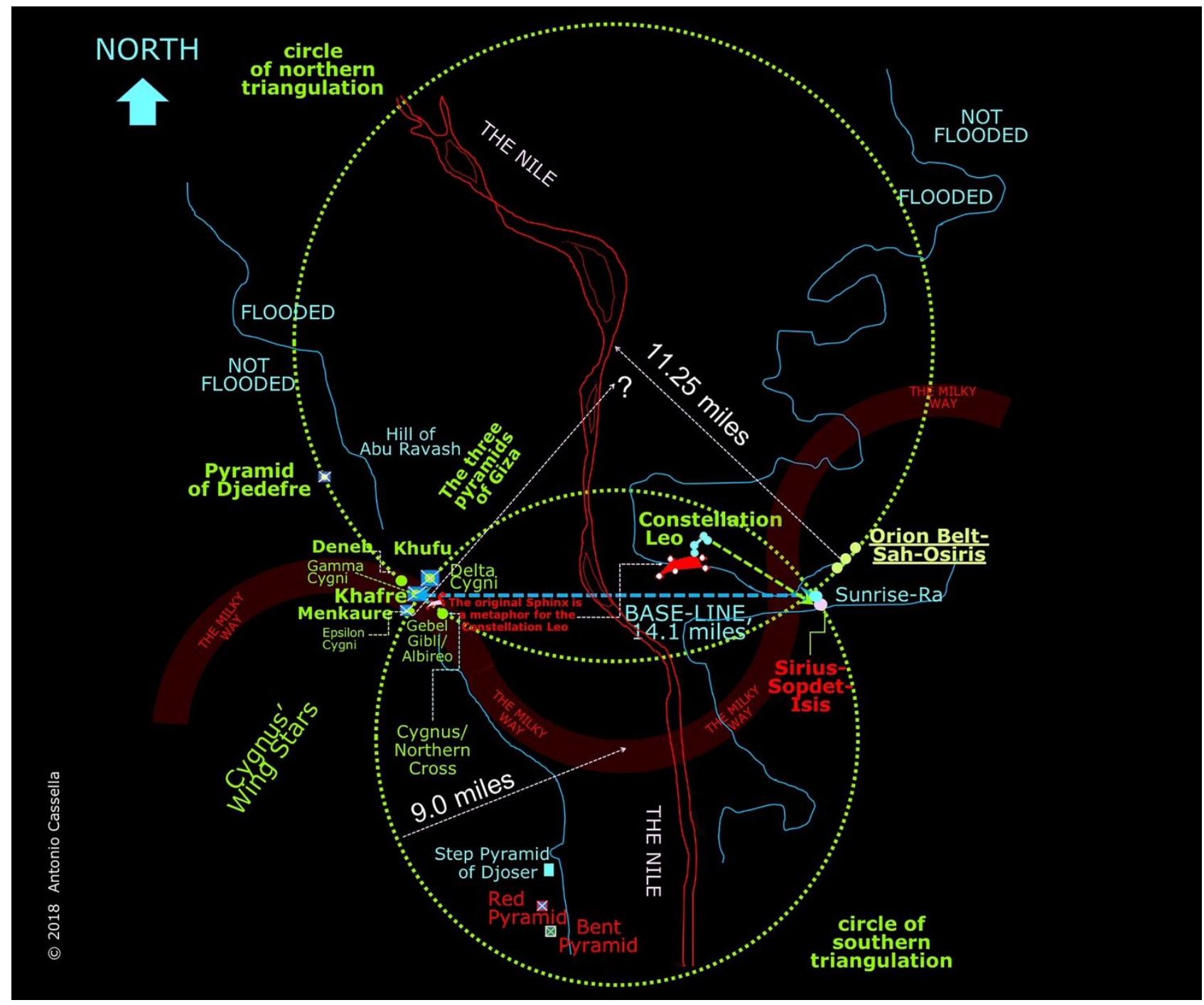

Figure 13. The hypothetical northern and southern circles of a primary triangulation in ancient Egypt

Although I did not explore where The Nile and the northern constellations went 4600 years ago, I noticed that:

a) The 10.52-mile straight line passing by the south-east corner of the three pyramids in Giza highlights a circle in a square of central Cairo;

b) counterclockwise, the northern circle crosses The Nile changing into a delta, Deneb, Khafre, the top of Gebel-Gibli-Albireo, the southern nothingness in which The Nile changes its course, the eastern end of the baseline, and the Orion Belt;

c) the circle of southern triangulation traverses the wings of Cygnus, the three pyramids of Giza, and the southern setting in which The Nile tricks the Compass Rose, before flooding the temple of Sirius-Sopdet-Isis.

Considering that only one circle passes by three points, the crossing of two circles in the five stars of the Northern Cross may have led ancient Egyptians into thinking that simultaneity in nature and the humane mind can devise new 
harmonies in front of the most challenging problems. Simultaneity makes the magical mark of Thoth!

On the wake of magic and the principle of Ubiquity, Thoth stood simultaneously at both sides of Ra's solar barge- a metaphor for the creative and social use of quantum computing by keen advisors in the House of Thoth.

As a former surveyor, I deducted that their two triangulation-circles helped imaginative Egyptian sages to keep track of the boundaries of properties and canals disavowed by the flooding of The Nile and avowed by humans' sweat and creative thought.

\subsection{Djedefre's Confirmation of a Thoughtful Master Plan}

The fact that Djedefre, Khufu's successor, did not build his pyramid in Giza has been taken as proof of the inexistence of a "master plan" behind Giza's monuments. Figure 13, however, suggests that the House of Thoth had a primary triangulation point near Abu Ravash. Therefore, I hypothesize that also Djedefre's pyramid will substantiate the master plan by highlighting a specific point on the circumference of the northern circle.

If the triangulation-circles traced in figure 13 were right, two temples should be found 14.1-mile east of the Pyramid of Khafre: The Temple of Ra (the sun-god) would stand at the eastern extreme of the baseline; and the second one (southeast of Ra) would represent Sirius-Isis-Sopdet. Furthermore, if ancient Egyptians had a land equivalent of the Orion Belt in the northern circle, the spade of excavators should also unearth three temples to Sah-Osiris, 1.8-mile of Ra, within a 42 degrees direction.

One cannot preclude the hypothesis that the southern circle was in place before Khufu. However, the Step Pyramid of Pharaoh Djoser and the Red and Bent pyramids of Pharaoh Sneferu lie inside it (figure 13); whereas Sneferu's first Meidum Pyramid was built about 27 miles south of its lower border.

Moreover, the fact that Sneferu abandoned Greek Tau, in the ratio perimeter/height (near 6.28) used in the Meidum Pyramid, suggests that he did not follow Vizier Imhotep's ways, stored in the Elephantine Island (before the first cataract) through the symbolic "Ankh" carried by a divine triad - Khnum (the "guardian" in the first attention), his consort Satis (the "warrior" in the second attention), and their daughter Anuket ("life" in the Third Attention).

\section{Conclusion}

By building 11000 years ago a monumental lioness in Giza, North-African "women-of-knowledge" left a memento to future generations of the dangers and opportunities hidden in the second attention. They also recognized the possibility of allying the second with the first attention. Indeed, quantum computing in Giza's original lioness points East to repetitive sunrise, the first attention, the baseline of the northern and southern circles of triangulation, the principles of classical computing; and even the principles of quantum computing:

Actually, in the area shared by the two circles devised by the House of Thoth, any point lies simultaneously in opposite worlds (Ubiquity); and opposite worlds share the same space at the same time (Coincidence).

Khufu's baseline and its associated two-circles crossing sustained the breathing of the Old Egyptian Kingdom between incontrollable thrusts of nature.

Djedefre's Pyramid near Abu Ravash might validate the northern circle; Khufu's pyramid, the southern circle; and the Sphinx, the baseline and the associated crossing of two triangulation-circles. These three hypotheses and the assumption that Khufu's Great Pyramid froze the triangulation devised by the House of Thoth compel me to conclude that: Khufu changed Giza's primeval lioness into the Sphinx.

By re-sculpting the head of Giza's lioness and placing the value 6.28 in the Great Pyramid, Khufu converted both monuments into standing metaphors for the union of nothingness and infinity in the Third Attention. In other words, Khufu pointed at the meaning of progress (figure 14): The marriage of classical locality in the first attention and quantum nonlocality in the coherence of the second attention renovates reality through decoherence in the Third Attention

After protecting the Sphinx in the manner suggested in Cassella (2017b), we could empower the Third Attention of women-leaders, save our grandchildren from witnessing chaos, sustain the breathing of the Sphinx and progress for 7000 more years, and cross the Milky Way to reach the seas of the planet that turns around "Proxima Centauri."

Saving the Sphinx agrees with:

a) Verse 86:1 of the Quran, "Wā As-Samā'i Wa at-Tāriq," ("Allah Governs by the Heaven [the left red arrow] and by the Evening Star" [the right green arrow]);

b) the quantum jump proposed by the Lord's Prayer;

c) the blessing that follows the passage from coherence to decoherence in the verses of the Holy Mary; and

d) the advice of Martin Luther King Jr. to us to either solve our problems or accept responsibility for doing nothing. 
The master plan hidden by Hemiunu and Khufu in the Sphinx and the Great Pyramid allows also the following thought: REVIVAL IN LIFE AND AFTER DEATH WILL ENRICH WHOEVER “CON-VINCES” OTHERS BY “WINNING-WITH” THEM.

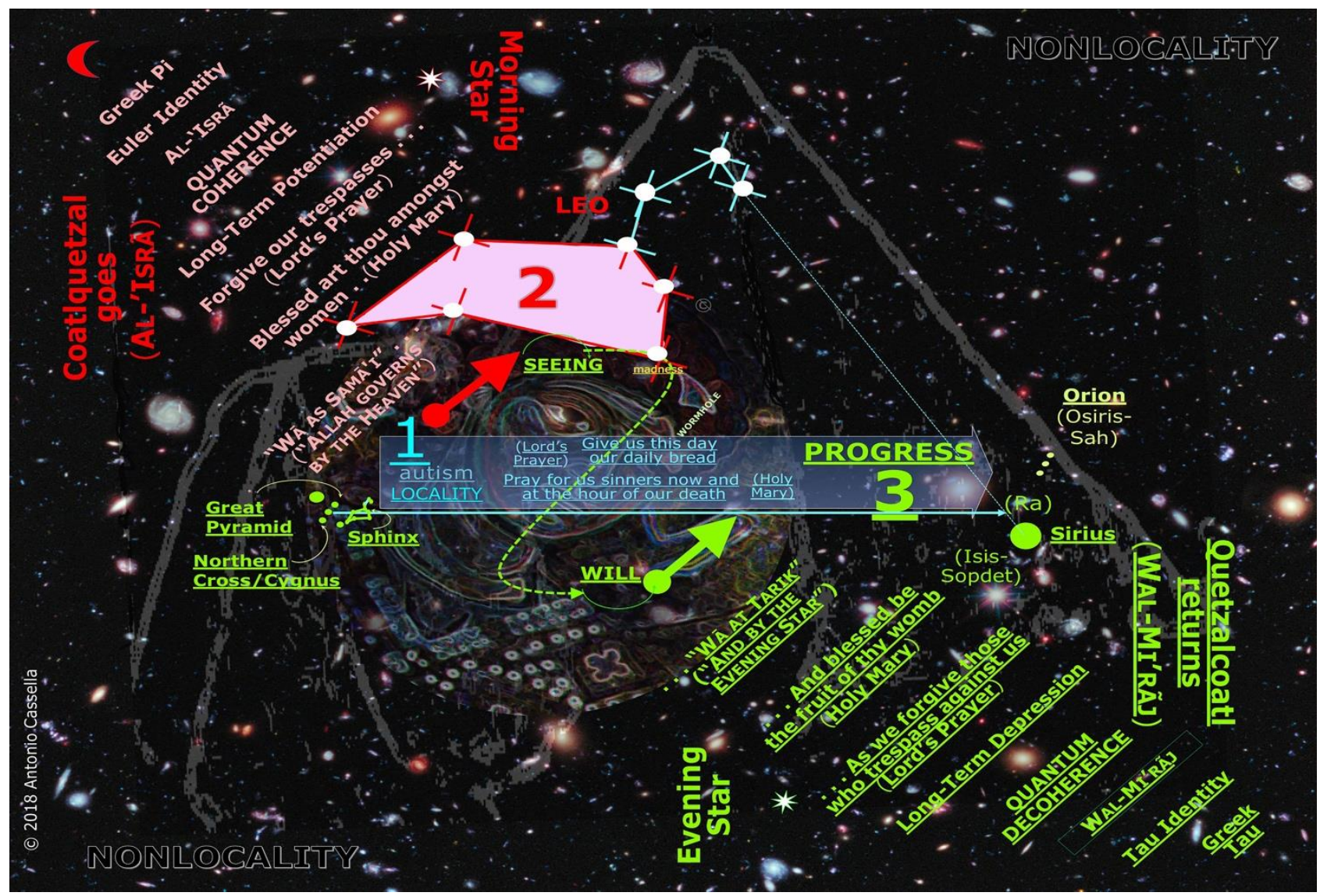

Figure 14. The roots of progress hidden in the Sphinx and the Great Pyramid ${ }^{6}$

The reader is reminded that others' attempts to replicate the hypotheses presented here may confirm or falsify them.

\section{Acknowledgements}

I wish to thank my wife Ligia Uribe for her suggestions.

\section{About the author}

Placing the words "Antonio Cassella" in the space of the author at Amazon Prime or Amazon Kindle will generate the list of his works. A biographical-sketch of the author can be found at "amazon.com/author/antoniocassella."

Antonio Cassella was born in Ethiopia in 1940. He went through high-school education in Italy and Venezuela. In 1965 he obtained from LUZ-Maracaibo a BSc in Petroleum Engineering. For the next 17 years Antonio developed new oil fields in the tidal bay of Maracaibo with Creole (a subsidiary of Esso/ExxonMobil), Lagoven, and PDVSA (Petróleos de Venezuela).

In 1976, he worked with EPRCO (Exxon Production Research) in Houston; and with Strategic Planning of PDVSA between 1983 and 1993. From 1994 to 1997 he was a scientist at MIT-CEEPR (Center for Energy and Environmental Policy Research), in Cambridge (MA). His research there led to establishing two scenarios of the global growth of population, energy, and the economy; i.e., until 2060 (Cassella, 2008).

In June 1997, his exploration of the psychological roots of autism and creative intelligence led to a master's degree in Psychology and the Award for Outstanding ALM Thesis in the Area of Natural and Human Sciences from Harvard University. In 2001 Antonio Cassella received from Universidad Nacional Experimental Simón Rodríguez (UNESR) in Caracas a doctoral degree of Research and Teaching in Sciences of Education.

\footnotetext{
${ }^{6}$ The image of the Archangel Gabriel in the sky was derived from a Wikimedia Commons' image (in the public domain) of a mosaic fresco drawn around $1130 \mathrm{AD}$ and kept in the Gelati Monastery of Kutaisi, Georgia.
} 
His writings in Italian, Spanish, and English (at Amazon Prime and Kindle) show that merging the local certainty sought by our autistic self with the nonlocal hope sought by our artistic self will allow us to restore the Commons of the Earth - among them, the atmosphere and the cycle of water.

Persons, enterprises, and institutions that face an extremely difficult question, or want to explore the implications of the logos heuristics into a problem of their own choosing through a half-day workshop, may e-mail Antonio Cassella at researchautism.1@gmail.com.

Research Autism LLC has published 12 documentaries (15 minutes each) about the logos heuristics. The new links are as follows:
English: (1) https://youtu.be/Py1RmzhVdO8; (2) https://youtu.be/HBU5RM3WnLE;
(3) https://youtu.be/4ug7QBm5yvo; and (4) https://youtu.be/sZrWSFFd0QA.
español: (1) https://youtu.be/y5xUVSgIiKw; (2) https://youtu.be/7m1uKY0VR4U;
(3) https://youtu.be/pHjPvIZLNRk; and (4) https://youtu.be/Ls7kDwkr-a8.
italiano: (1) https://youtu.be/2oA4f6osGHI; (2) https://youtu.be/nUzeOOgC 8A;
(3) https://youtu.be/RIqluy0b-Qs; and (4) https://youtu.be/C5JbBneJKAg.

\section{References}

Andrew, G. (1999). The epic of Gilgamesh. London: Penguin Books.

Anonimo, G. (16 ${ }^{\mathrm{mo}}$ secolo; 1893). Il Codice dell'Anonimo Gaddiano nella Biblioteca nazionale di Firenze. http://vinciana.blogspot.com/2014/05/1893-c-de-fabriczy-il-codice.html

Baron-Cohen, S. (1995). Mindblindness. Cambridge, MA: MIT Press.

Bauval, R., \& Gilbert, A. (1994). The Orion mystery: Unlocking the secrets of the Pyramids. London: Heinemann.

Caramazza, A. (1994). Parallels and divergences in the acquisition and dissolution of language. Philosophical Transactions of the Royal Society of London, Series B. 346, 121-127. https://doi.org/10.1098/rstb.1994.0136

Cassella, A. (1997). Self-other differentiation and self-other integration from the perspectives of language development and autism. Unpublished master's thesis. Harvard University, USA.

Cassella, A. (2000). Fundamentos cognitivos y semióticos de la creatividad: Aportes del autismo. (Tesis doctoral con mención publicación). Universidad Nacional Experimental Simón Rodríguez (UNESR), Caracas, Venezuela.

Cassella, A. (2002a). El desarrollo de la inteligencia social: Aportes del autismo. Maracaibo, Venezuela: Ediluz.

Cassella, A. (2002b). The Flameless Fire: From autism to creative intelligence. Quincy (MA): Logosresearch.

Cassella, A. (2008). Readjusting what we know with what we imagine. In R. Allen (Ed.), Human ecology economics: A framework for global sustainability (pp. 230-257). London: Routledge.

Cassella, A. (2011, June). Autism and the interplay of deterministic and quantum information processing in the act of creation. Neuroquantology, 9(02), 271-287.

Cassella, A. (2013). Psychological roots of social and linguistic deficiencies in autism and the distinction between classical and quantum neural computing. In V. B. Patel, V. B. Preedy, \& C. R. Martin (Eds.), The comprehensive guide to autism (pp. 1219-1242). London: Springer.

Cassella, A. (2016). The psychological roots of creativity in messages left by Leonardo da Vinci, Giorgio Vasari, and a Neanderthal troglodyte. Journal of Arts and Humanities, 5(8), 12-28. https://doi.org/10.18533/journal.v5i8.966

Cassella, A. (2017a). Re-directing climate change and terrorism by allying classical with quantum neural computing. International Journal of Social Studies, 5(6), 94-115. https://doi.org/10.11114/ijsss.v5i6.2439

Cassella, A. (2017b) Freeing Leonardo da Vinci's Fight for the Standard in the Hall of the Five Hundred at Florence's Palazzo Vecchio. International Journal of Social Science Studies, 5(10), 01-16. https://doi.org/10.11114/ijsss.v5i10.2657

Cassella A. (2018a). A psychological view of complex numbers through classical and quantum computing. International Journal of Social Science Studies, 6(1), 66-81. https://doi.org/10.11114/ijsss.v6i1.2872

Cassella A. (2018b). Exploring the social link between cerebral and cerebellar neural ensembles through a falsifiable psychological heuristics. International Journal of Social Science Studies, 6(2), 69-93, 
https://doi.org/10.11114/ijsss.v6i2.2934.

Cassella, A. (2018c). Thus returned Quetzalcoatl: An interview with Antonio Cassella concerning the Dance of locality and nonlocality. Melbourne (FL): Research Autism ( $4^{\text {th }}$ edition at Amazon Prime and Kindle).

Cassella, A. (2018d). An unlawful look at an extraordinary theory-of-everything: Answers to 15 questions concerning the dance of locality with nonlocality. Melbourne (FL): Research Autism ( $4^{\text {th }}$ edition at Amazon Prime and Kindle).

Castaneda, C. (1972). Journey to Ixtlán: The lessons of Don Juan. New York: Simon and Schuster.

Collins, A. (2007). The Cygnus mystery: Unlocking the ancient secret of life's origin in the cosmos. London: Watkins Publishing.

Fairall, A. P. (June 1999). Precession and the layout of ancient Egyptian pyramids. Astronomy and Geophysics, 40(3), 3-4. https://doi.org/10.1093/astrog/40.3.3.4

Guillemette, A. (1997). Egypt in the Age of the Pyramids. Ithaca: Cornell University Press.

Hays, H. D., Imbrie, J., \& Shackleton, N. J. (1976). Variations in the Earth's orbit: Pacemaker of the Ice Ages. Science, 194(4270), 1121-1132. https://doi.org/10.1126/science.194.4270.1121.

IPCC-WG1. (2007). Intergovernmental Panel on Climate Change. Fourth Assessment Report. Summary for Policymakers: A Report of Working Group I. IPCC-WMO.

Ito, M. (2011). Ito, Masao. The cerebellum: Brain for an implicit self. Upper Saddle River, NJ: Pearson Ed, 2011.

Katznelson, M. (1991). La Biblia: hebreo-español. Tel Aviv: Sinaí.

Laertius, D. (6 ${ }^{\text {th }}$ century CE, 2017). In Tiziano Dorandi (Ed.) Lives of Eminent Philosophers. Cambridge: Cambridge University Press.

Lehner, M. (1997). The complete Pyramids. New York: Thames and Hudson.

Milankovitch, M. (1998). Canon of insolation and the ice-age problem. Belgrade: Textbook Publishing Company.

Pagels, E. (1996). The origin of Satan. New York: Vintage Books.

Perner, J. (1991). Understanding the representational mind. Cambridge (MA): MIT Press.

Povinelli, D. J, Landau, K. R, \& Perilloux, H. K. (1996). Self-recognition in young children using delayed versus live feedback: Evidence of a developmental asynchrony. Child Development, 67, 1540-1554. https://doi.org/10.2307/1131717

Reader, C. (March 2006). Further considerations on development at Giza before the $4^{\text {th }}$ dynasty. www.Palk/Arch.ni, archaeology of Egypt/Egyptology. Retrieved on June 18, 2018.

Rodríguez-Vidal, J., d'Errico F., Giles Pacheco, F., Blasco, R., Rosell, J., Jennings, R. P., ... Finlayson, C. (September 2014). A rock engraving made by Neanderthals in Gibraltar. Proceedings of the National Academy of Sciences of the United States of America, 111(37), 13301-13306. https://doi.org/10.1073/pnas.1411529111

Shocht, R. M. (1995). Response in Archeology Magazine to Zahi Hawass and Mark Lehner. In C. M. Dowell (Ed.) Circular Times.

Stadelmann, R. (2003). The Great Sphinx of Giza. In Zahi Hawass (Ed), Egyptology at the dawn of the $21^{\text {st }}$ century: Proceedings of the $8^{\text {th }}$ International Congress of Egyptologists (pp. 464-469). Cairo: American University Press.

Vasari, G. (1550). Le vite de 'più eccellenti architetti, pittori, et scultori italiani, da Cimabue insino a'tempi nostri. Torino (1986), Einaudi.

Ward, P. D. (October 2006). "Impact from the Deep." Scientific American, 295, 64-71. https://doi.org/10.1038/scientificamerican1006-64

Zahi, H. (1998). The secrets of the Sphinx: Restoration Past and Present. Cairo: The American University.

Zaitchik, D. (1990). "When representations conflict with reality: The preschooler's problem with false beliefs and 'false' photographs." Cognition, 35, 41-68. https://doi.org/10.1016/0010-0277(90)90036-J

\section{Copyrights}

Copyright for this article is retained by the author(s), with first publication rights granted to the journal.

This is an open-access article distributed under the terms and conditions of the Creative Commons Attribution license which permits unrestricted use, distribution, and reproduction in any medium, provided the original work is properly cited. 